\title{
Некоторые особенности двувидовых глаголов и их восприятие билингвами и монолингвами
}

\author{
Anna Pavlova (Mainz)/Анна Павлова (Майнц)
}

\begin{abstract}
The Russian language contains a number of bi-aspectual verbs, which may be used as both imperfective and perfective. A comparison of several dictionaries shows that lexicographers hold very different opinions as to whether a given verb is bi-aspectual or not. A comparison of verbs labeled as bi-aspectual in a dictionary against real usage of some bi-aspectual verbs in texts indicates that the dictionaries are not always reliable and that the lexicographic marking of bi-aspectual verbs is rather founded on tradition than on actual usage in texts.
\end{abstract}

\section{1 Введение}

В русском языке существует немалое количество так называемых «двувидовых» глаголов (ДГ). Они отличаются тем, что способны выступать как в совершенном, так и в несовершенном виде - иногда поочередно, а иногда даже одновременно: трудно бывает решить, что перед нами - СВ или НСВ. Например, в рекламе турагентства: $M b l$ организуем замечательный отдых в Новой Зеландии - сейчас (в принципе, вообще, всегда - в этом состоит наша работа) или в будущем (конкретно, для вас, дорогие клиенты)? Если сейчас, то глагол выступает в своей НСВ-ипостаси, а если в будущем, то перед нами, скорее, СВ. В некоторых своих употреблениях (особенно в случае форм настоящего/простого будущего времени или - реже - прошедшего) ДГ напоминают известные картинки-загадки: в одной картинке спрятано две (молодая женщина и старуха, цветочная ваза и лицо), и зритель видит то одну, то другую (а иногда видит только одну, не замечая, что есть другая).

Порой видовое противоречие как будто снимается, становится несущественным. Например, воспринимая фразу Во Франции вас тестировали на детекторе лжи, не задаешься вопросом, идет ли здесь речь о продолжительном (или многократном) действии или о результативно-однократном: для семантики высказывания это не особенно существенно.

В некоторых высказываниях вид ДГ можно определить однозначно благодаря контексту или просто здравому смыслу: Мы как раз минуем неприятный участок пути - настоящее время, несовершенный вид глагола (НСВ). Миновал год - совершенный вид (CB). Если глагол многозначен, то одно его значение может тяготеть к одному виду, а другое к другому: Твои слова меня глубоко ранят (что делают? - НСВ). - A mbl 
не боишься, что тебя ранят? (что сделают? - СВ). Речь может идти только о тенденции, так как в принципе можно представить себе и противоположные примеры например, в прошедшем времени: Твои слова меня тогда (что сделали?) глубоко ранили; Сухая трава (что делала?) ранила ноги.

А иногда трудно решить, что перед нами - НCВ или СВ: Печать времени не минует никого. Здесь как будто совмещаются оба вида в одной форме - то ли перед нами будущее время, то ли настоящее. Еще явственнее «снятие» видовой дифференциации проявляется в употреблении ДГ, именующих действие в ясно означенном реальном будущем: Преступника казнят завтра на Манежной площади; Они женятся в субботу, без свидетелей. Что здесь перед нами - грамматическое настоящее, отнесенное к временно́му отрезку «будущее», или простое будущее время? Граница между СВ и НСВ здесь проницаема, эфемерна. Отмечая эту неоднозначность, неразрешимость проблемы видовой отнесенности ДГ даже в некоторых широких контекстах, Зализняк/Микаэлян/Шмелев, авторы книги «Русская аспектология: в защиту видовой пары», считают, что, тем не менее, «ни в коем случае» нельзя говорить «о синкретичном выражении в одной глагольной форме сов. и несов. вида. Речь идет лишь о том, что одна и та же форма может выражать два различных смысла, которые могут быть не всегда достаточно четко дифференцированы, и к тому же не всегда ясно, который из них имел в виду автор в данном конкретном случае» (Зализняк и др. 2015: 83-84).

Активное использование форм времени русского глагола в переносном значении формы настоящего для обозначения как прошедших (Выхожу я вчера из дома...), так и будущих событий (Mbl прилетаем завтра вечерним рейсом) - привело некоторых грамматистов в XIX веке к выводу, что в русском языке временны́е формы целиком зависят от глагольного вида; категория времени в русском языке аморфна, грамматически не оформлена - по сути, заменена видом (Петрухина 2009: 176). Не вдаваясь в эту научную дискуссию, имеющую давнюю традицию и прослеживаемую до сих пор (подробнее об этом см. Гаспаров 2006), заметим, что и в немецком языке, не имеющем выраженной категории вида, футур все чаще заменяется презенсом, причем едва ли не активнее, чем в русском. Уже в немецкой грамматике 1967 г. презенс в сравнении с футуром именуется «Normaltempus» (Jung 1967: 231). Во всех авторитетных современных немецких грамматиках отмечается, что формы футура отчетливо сдвигаются по своей функции в сторону выражения модальности. Однако эти тенденции пока не дают оснований отрицать наличие грамматических форм настоящего и будущего времени в немецком языке, и футур всё еще употребляется в современном немецком языке в значении будущего (Ballweg 1988). Не будем отрицать наличие временны́х форм и в русском, оставаясь на традиционной точке зрения, хотя в случае ДГ, как уже было сказано, различить настоящее и будущее иногда действительно сложно, а порой и вовсе невозможно.

В противоположность грамматистам, считающим, что у всех русских глаголов имеется категория вида и что эта категория в паре вид/время является ведущей и основной, а может быть, даже вытесняющей категорию времени, существуют скептики, которых «двуликость» ДГ заставляет усомниться в том, входят ли они вообще в категорию вида (Gladney 1982). Однако в русском языке имеется, как известно, немалое число и ISSN 1615-3014 
одновидовых глаголов, которые, несмотря на отсутствие пары, осознаются носителями языка как выражающие видовую категорию (например, вытворять, любезничать, поблёскивать, опасаться - только НСВ; встрепенуться, обмолвиться, разрумяниться - только СВ). Думается всё же, что все русские глаголы подпадают под категорию вида, хотя двувидовые и одновидовые глаголы, несомненно, сдвигаются к периферии этой категории, если представлять ее себе в виде поля, исходя из полевой структуры языковой системы в целом. «Двувидовые глаголы в современном русском языке представляют собой периферийное явление, так как языковая система стремится к тому, чтобы грамматическим различиям соответствовали формальные» (Зализняк и др. 2015: 87). ДГ являются «неизбежным проявлением асимметрии в системе русского глагола» (Авилова 1968: 78).

Перед грамматистами встает и проблема тождественности ДГ в их НСВ и СВ-ипостаси: один ли это глагол, два омонимичных или даже два разных? Горобец пишет по этому поводу: «Двувидовые глаголы за всю историю их изучения рассматривались преимущественно как синкретичные формы, реже - как грамматические омонимы, но всегда - как разновидности одной лексической единицы». Автор диссертационного исследования предлагает «рассмотрение глаголов, традиционно признаваемых биаспективами, как отдельных единиц, каждая из которых имеет свою собственную систему словоизменения с омонимией в ряде форм» (Горобец 2008: 6). Однако подробнее затронутая дискуссия в настоящей статье обсуждаться не будет, тем более что вопрос о трактовке категории вида как словоизменительной или словоклассифицирующей не решен в целом и, видимо, не имеет решения в принципе (см. об этом подробнее в кн.: Зализняк и др. 2015: 19-21). Для простоты каждый представитель группы ДГ здесь будет именоваться «глагол» (а не «глаголы»).

При том, что восприятие фраз с ДГ бывает затруднено омонимичностью, не разрешаемой в контексте, можно предположить, что при порождении речи говорящий всегда имеет в виду какой-то один из видов. Так, произнося фразу Этиологию серозных менингитов, как и паротитов, до 2001 г. не верифицировали (НКРЯ), он, по-видимому, имеет в виду либо прошедшее время глагола верифищировать в его СВ-ипостаси (Чего не сделали?), либо прошедшее того же глагола в его варианте НСВ (Чего не делали?). Сравнение восприятия реципиента с интенцией говорящего относительно ДГ (выяснение, то ли говорящий хотел сказать и правильно ли его поняли) могло бы быть плодотворной задачей, однако в рамках данного исследования проводиться не будет.

Существуют двувидовые глаголы (организовать, реализовать, опротестовать, согласовать и др.), которые как будто «пытаются избавиться» от двувидовости тем, что при них возникают пары имперфективного значения: организовывать, реализовывать, опротестовывать, согласовывать. Согласно Горобец (2008: 21), глаголы этого типа составляют только 7,3\% от всех ДГ. Другие, наоборот, «обрастают» перфективными приставочными парами: тестировать - протестировать, оттестировать; бронировать - забронировать; жениться - пожениться, наследовать - унаследовать (подробное описание пар, образующихся для ДГ, см.: Черткова, Чанг 1998). В Горобец (2008: 22) указано, что доля глаголов, имеющих как омонимичный, так и 
неомонимичный префиксальный коррелят, составляет $11,7 \%$ от общего числа ДГ. ${ }^{1}$ Есть и другие данные. Так, согласно работе Тихонова (1998: 211), порядка 500 из 1500 (т.е. одна треть!) ДГ способны создавать видовые корреляции с помощью префиксов. Расхождение в данных в разных работах вызвано тем, что большое число префиксальных образований не отыскивается в словарях; поэтому в одной работе речь может идти о зафиксированных в лексикографии случаях, а в другой о потенциальной способности ДГ создавать префиксальный вариант СВ. В работе Janda (2007) детально описываются общие принципы образования перфективных и имперфективных глаголов, создающих «видовые кластеры». Но, несмотря на образование однозначных видовых пар, те же глаголы продолжают сохранять свою биаспектуальность и употребляться именно как двувидовые (ср. Горобец 2008: 22, Петрухина 2009: 83-84), из-за чего фразы Я бронирую для нас два билета на ночной поезд; Он наследует всё состояние бабушки; Мы организуем встречу; Они женятся по любви по-прежнему можно понимать как минимум двояко: как содержащие глагол либо в настоящем, либо в будущем грамматическом времени, а возможно, и в третьем модусе: как формы настоящего времени, употребленные для обозначения реального будущего. И это несмотря на наличие вариантов забронировать (CВ), унаследовать (СВ), организовывать (НСВ), пожениться (СВ). Впрочем, для ДГ, имеющих имперфективные пары, их биаспектуальность проявляется только в настоящем/простом будущем и не ощущается в прошедшем: формы кто-л. что-л. реализовал, организовал, согласовал воспринимаются исключительно как представители СВ (ср. организовывал, реализовывал, согласовывал - НСВ), в то время как реализует, организует, согласует могут представлять как СВ, так и НСВ (ср. Зализняк и др. 2015: 86).

По критерию «происхождение» Горобец выделяет три группы ДГ:

1) старославянские или древнерусские (венчать, женить, живописать, колесовать, наследовать и многие другие - всего около 70 глаголов); 2) заимствованные из неславянских, преимущественно европейских, языков (глаголы, кончающиеся на ировать, типа амортизировать, нокаутировать, оккупировать); таких в группе ДГ большинство (более 90\%); 3) незаимствованные глаголы позднего происхождения, созданные по аналогии с заимствованными (военизировать, складировать, славянизировать и др.); их доля в общем количестве ДГ мала (около 1\%), но сам факт их наличия в языке чрезвычайно показателен, так как демонстрирует продуктивность соответствующей модели словообразования, а также подтверждает, что категория ДГ не обнаруживает тенденции к распаду (Горобец 2008: 20-21), хотя «материалы литературных памятников и словарей показывают увеличивающееся количество глаголов с формально выраженным видом за период XVIII-XX вв.» (Авилова 1968: 68), причем к середине XIX века количество приставочных образований у глаголов с суффиксом -ова заметно возрастает, и благодаря этому увеличивается удельный вес

\footnotetext{
1 Трудность точных подсчетов общего числа ДГ обусловлена тем, что словари расходятся в фиксации биаспектуальности (один и тот же глагол в одном словаре может быть выведен как двувидовой, а в другом как одновидовой); а при анализе текстов лингвист сталкивается, с одной стороны, с новообразованиями (окказионализмами), с другой - с множеством неясных случаев. Кроме того, язык постоянно развивается и меняется, в него регулярно заимствуются все новые и новые глаголы из других языков. Поэтому точно вычислить общее количество ДГ в русском языке вряд ли возможно.
}

ISSN 1615-3014 
совершенного вида (там же: 69). С другой стороны, наблюдается и обратное явление: некоторые пары «НСВ без префикса - СВ с префиксом» со временем распались, и изначально двувидовой глагол снова обретает былую биаспектуальность (оженить, исказнить - сегодня эти глаголы можно считать устаревшими, ср. Потехина 2007: 115). Потехина приводит примеры продуктивности модели образования ДГ, не зафиксированные словарями, но употребляемые в речи (бананизировать, тонировать) (там же: 115). Она же демонстрирует на большом количестве примеров продуктивность префиксации ДГ, опять-таки не фиксируемой словарями: проконстатировать, conпонировать, саккумулировать и др. (там же). Таким образом, налицо как сохранение и даже увеличение общего количества ДГ путем новообразований и все новых заимствований, так и попытки избавиться от двусмысленности и размежевать НСВ и СВ путем префиксации и образования новых слов, не отыскиваемых в словарях, устойчиво наблюдаемые в живой, особенно в разговорной некодифицированной речи.

Толковые словари обычно отмечают принадлежность ДГ к обоим видам. Однако употребление некоторых русских глаголов нередко расходится с их «аттестацией»в качестве одно- или двувидовых в толковых словарях. Так, глагол обжаловать трактуется большинством словарей (см. табл. 1) как глагол совершенного вида (CB), а употребляется (хотя и изредка) в настоящем времени в роли глагола несовершенного вида (НСВ): Ходим надопросы, обжалуем действия следствия («Эхо Москвы»); Военнослужащая своей вины не признала, запретив адвокатам обжаловать приговор (портал «Диалог»). Относительно некоторых других глаголов словари русского языка расходятся: так, глаголы интегрировать, обнародовать, скандировать и многие другие одними словарями трактуются как одновидовые, другими как двувидовые. Сравнение толковых словарей по критерию «определение видов потенциально двувидовых глаголов», а затем сопоставление этих данных с реальными употреблениями в текстовых корпусах представляется важной задачей как для лексикографии, так и для дидактики.

Далее, стоило бы осветить психолингвистический аспект проблемы ДГ, а именно их восприятие в речи. Представляется, что толкование некоторых ДГ во многом определяется местом наиболее сильного (логического, главного) ударения: рематичность глагола (глагол образует «узкий фокус») побуждает расценить его скорее как CВ: Mbl обору́дуем икольные кабинеть! - такая фраза вероятнее отнесена к будущему, чем к настоящему, обнаруживает характеристики $\mathrm{CB}$, в то время как отсутствие главного ударения на глаголе коррелирует с его трактовкой как НСВ, употребленного в настоящем времени: Мы оборудуем школьные кабине́тыл («широкий фокус»: ремой является словосочетание оборудуем школьные кабинеты). Гипотеза восприятия вида ДВ в зависимости от места логического ударения будет проверена экспериментально.

Еще одна гипотеза, которую предстоит подтвердить или опровергнуть, состоит в том, что ДГ редко трактуются реципиентами как таковые даже во фразах, «вырванных» из контекста (например, в заголовках или первых фразах текстов, когда правый контекст еще не прочитан). Предполагается, что испытуемые в эксперименте на восприятие будут чаще выбирать либо один, либо другой вид - а именно тот, к которому они 
больше привыкли, встречая употребления соответствующего глагола в текстах. (Ср. понятия Alpha-Verben и Betha-Verben, введенные в работе: Lehmann 1993).

Далее, следует проверить, все ли грамматические формы ДГ, допустимые чисто теоретически (в первую очередь, сложное будущее время), воспринимаются в речи как нормативные и узуальные.

При обучении билингвов - будущих переводчиков - русской грамматике обращает на себя внимание резкое размежевание группы студентов, для которых русский язык является первым и основным (L1), с группой, для представителей которой в качестве основного («сильного») выступает немецкий: в то время как во всех прочих «проблемных» темах члены обеих групп делают приблизительно одни и те же ошибки, в области глагольных видов билингвы с русским как основным ошибок не допускают. Тем не менее, интересно сравнить восприятие двувидовых глаголов студентамибилингвами с русским в качестве первого и основного (доминантного) языка, проживающими в Германии, и монолингвами с родным русским, проживающими в России. Выдвигается следующая гипотеза: разброс данных (дисперсия) при определении глагольного вида у билингвов будет выше, чем у монолингвов. Иными словами, монолингвы будут более единодушны в своих оценках видовой принадлежности ДГ, чем билингвы.

Итак, в статье будут представлены несколько аспектов одной темы:

1) результаты сравнения нескольких толковых словарей относительно отражения в них двувидовой природы некоторых ДГ, отобранных по методу случайной выборки;

2) результаты сравнения словарных описаний с данными текстовых корпусов;

3) грамматические формы ДГ (причастия, будущее время) в аспекте их нормативности по данным Национального корпуса русского языка;

4) описание эксперимента по восприятию письменных фраз, включающих ДГ, билингвами с русским языком как первым и доминантным и монолингвами с родным русским;

5) описание эксперимента по восприятию видовой природы ДГ в зависимости от места главного фразового ударения (восприятие на слух) монолингвами.

Однако прежде чем перейти к выполнению поставленных задач, стоит хотя бы кратко осветить аналогичные уже проведенные исследования по восприятию ДГ и их результаты.

\section{2 Краткое описание исследований по восприятию ДГ, проводившихся другими лингвистами}

Автору настоящей работы известны еще два экспериментальных исследования по восприятию ДГ: Chromý (2014) (для чешских ДГ) и Piperski (2016) (для русских ДГ). В основе работы Chromý (2014) лежит предположение, что ни один ДГ не осознается в речи как воплощающий оба вида, а всегда интерпретируется как представитель лишь 
одной своей ипостаси - либо НСВ, либо СВ. Хромы предлагал 60 респондентам заменять в предложениях заимствованные глаголы, среди которых попадались ДГ, синонимичными «исконными», и проверял, в каком грамматическом виде употреблялись глаголы-заменители. Всего он исследовал 14 ДГ, предлагавшихся испытуемым в настоящем или в прошедшем времени. Хромы также предположил, что ДГ в настоящем времени интерпретируется скорее как НCB, а в простом прошедшем как $\mathrm{CB}$, даже в одинаковых контекстах. По результатам эксперимента обе гипотезы подтвердились для всех глаголов, кроме двух. В формах прошедшего времени как представители СВ интерпретировались в первую очередь глаголы моментального действия. Автор исследования высказывает интересное предположение, требующее экспериментальной проверки в будущем: опознание ДГ как СВ или НСВ, возможно, зависит в том числе и от формы подлежащего.

Пиперский провел обширный подсчет употреблений ДГ в Национальном корпусе русского языка (НКРЯ) по эпохам, изучил грамматические формы деепричастий, образованных от ДГ, также по эпохам. Он исследует НКРЯ для 966 глаголов, двувидовость которых устанавливается по Грамматическому словарю русского языка Зализняка 1977 года издания. Исследование деепричастий показало, что для 500 ДГ форм деепричастий в НКРЯ не обнаружилось. Автор объясняет это низкой частотностью деепричастий в целом и относительно низкой частотностью ДГ в частности. Кроме кропотливых подсчетов по НКРЯ, Пиперский провел эксперимент по восприятию 47 ДГ вне контекста (только словоформы, варьирующиеся по времени, лицу и числу). «Промежуточных» ответов типа «неясный случай» или «возможно одно или другое» в эксперименте Пиперского нет: все ответы даны по принципу дизъюнкции. Общий вывод Пиперского состоит в том, что ДГ по природе своей очень разные и что среди этой обширной группы одни ДГ ведут себя в речи как одновидовые глаголы типа НСВ, другие как одновидовые $\mathrm{CB}$, а между этими полюсами имеется группа «собственно двувидовых» глаголов.

\section{3 Сравнение данных о ДГ в одноязычных словарях}

Для сравнения по методу случайной выборки были отобраны 20 глаголов из Списка одно- и двувидовых глаголов (Павлова 2001). ${ }^{2}$ Если по крайней мере в одном из сравниваемых словарей глагол характеризуется принадлежностью к обоим видам, ${ }^{3}$ то

\footnotetext{
2 Словник одно-и двувидовых глаголов был составлен автором настоящей статьи пять лет назад на основании сравнений данных о видовой принадлежности, приводимых в различных одноязычных словарях в сети (см. ссылку в списке словарей в конце данной статьи). Еще более подробный, но не свободный от ошибок анонимный словник двувидовых глаголов составлен относительно недавно, см. https://ru.wiktionary.org/w/index.php?title=\%D0\%9A $\%$ D0\%B0\%D1\%82\%D0\%B5\%D0\%B3\%D0\%BE $\%$ D $1 \% 8$ 0\%D0\%B8\%D1\%8F:\%D0\%94\%D0\%B2\%D1\%83\%D0\%B2\%D0\%B8\%D0\%B4\%D0\%BE\%D0\%B2\%D1\%8B $\%$ D0\%B5_\%D0\%B3\%D0\%BB\%D0\%B0\%D0\%B3\%D0\%BE\%D0\%BB\%D1\%8B\&pageuntil=0D0\%B4\%D0 $\%$ B5\%D0\%B0\%D0\%BA\%D1\%82\%D0\%B8\%D0\%B2\%D0\%B8\%D1\%80\%D0\%BE\%D0\%B2\%D0\%B0\%D1 $\% 82 \% \mathrm{D} 1 \% 8 \mathrm{C} \# \mathrm{mw}$-pages [09.05.2017].

3 Обычно двувидовость отражена в словарях сокращениями «несов. и сов.» или «св, нсв»; некоторые словари указывают на то, что один вид более редко встречается, например: «СВ, реже НСВ». В настоящей таблице выбран для удобства один и тот же способ обозначения, независимо от того, как
} 
он входит в список двувидовых глаголов. ${ }^{4}$ Табличная форма дает возможность легко сравнить мнения лексикографов относительно одних и тех же глаголов. ${ }^{5}$ Для сравнения привлекаются следующие лексикографические источники: Ушаков (1935); ССРЛЯ (1948-1965); Daum/Schenk (1954); Ожегов (1996); Кузнецов (2006); Зализняк (2008); БАC (2004-2016).

\begin{tabular}{|c|c|c|c|c|c|c|c|}
\hline Глагол & Ушаков & $\begin{array}{l}\text { Daum/ } \\
\text { Schenk }\end{array}$ & Ожегов & Кузнецов & Зализняк & ССРЛЯ & БАC \\
\hline амнистировать & $\mathrm{HCB}, \mathrm{CB}$ & $\mathrm{HCB}, \mathrm{CB}$ & $\mathrm{HCB}, \mathrm{CB}$ & $\mathrm{HCB}, \mathrm{CB}$ & $\mathrm{HCB}, \mathrm{CB}$ & $\mathrm{HCB}, \mathrm{CB}$ & $\mathrm{HCB}, \mathrm{CB}$ \\
\hline брони́ровать & $\mathrm{HCB}, \mathrm{CB}$ & HCB & $\mathrm{HCB}, \mathrm{CB}$ & $\mathrm{HCB}, \mathrm{CB}$ & $\mathrm{HCB}, \mathrm{CB}$ & глагола нет & $\mathrm{HCB}, \mathrm{CB}$ \\
\hline интегрировать & $\mathrm{HCB}, \mathrm{CB}$ & HCB & $\mathrm{HCB}, \mathrm{CB}$ & $\mathrm{HCB}, \mathrm{CB}$ & $\mathrm{HCB}, \mathrm{CB}$ & $\mathrm{HCB}, \mathrm{CB}$ & $\mathrm{HCB}, \mathrm{CB}$ \\
\hline исповедовать & $\mathrm{HCB}, \mathrm{CB}$ & $\mathrm{HCB}, \mathrm{CB}$ & $\mathrm{HCB}, \mathrm{CB}$ & $\mathrm{HCB}, \mathrm{CB}$ & $\mathrm{HCB}, \mathrm{CB}$ & $\mathrm{HCB}, \mathrm{CB}$ & $\mathrm{HCB}, \mathrm{CB}$ \\
\hline локализовать & $\mathrm{HCB}, \mathrm{CB}$ & $\mathrm{HCB}, \mathrm{CB}$ & $\mathrm{HCB}, \mathrm{CB}$ & $\mathrm{HCB}, \mathrm{CB}$ & $\mathrm{HCB}, \mathrm{CB}$ & $\mathrm{HCB}, \mathrm{CB}$ & $\mathrm{HCB}, \mathrm{CB}$ \\
\hline миновать & $\begin{array}{l}\text { СВ и } \\
\text { (редко) } \\
\text { НСВ } \\
\end{array}$ & $\mathrm{HCB}, \mathrm{CB}$ & $\mathrm{HCB}, \mathrm{CB}$ & $\mathrm{HCB}, \mathrm{CB}$ & $\mathrm{HCB}, \mathrm{CB}$ & $\mathrm{HCB}, \mathrm{CB}$ & $\mathrm{HCB}, \mathrm{CB}$ \\
\hline надругаться & $\mathrm{CB}$ & $\mathrm{CB}$ & $\mathrm{CB}$ & $\mathrm{CB}$ & $\mathrm{CB}$ & $\mathrm{HCB}, \mathrm{CB}$ & CB \\
\hline напутствовать & $\mathrm{HCB}, \mathrm{CB}$ & $\mathrm{HCB}, \mathrm{CB}$ & $\mathrm{HCB}, \mathrm{CB}$ & $\mathrm{HCB}, \mathrm{CB}$ & $\mathrm{HCB}, \mathrm{CB}$ & $\mathrm{HCB}, \mathrm{CB}$ & $\mathrm{HCB}, \mathrm{CB}$ \\
\hline обжаловать & $\mathrm{CB}$ & $\mathrm{CB}$ & $\mathrm{CB}$ & $\mathrm{CB}$ & $\mathrm{HCB}, \mathrm{CB}$ & $\mathrm{CB}$ & $\mathrm{CB}$ \\
\hline обнародовать & $\mathrm{CB}$ & $\mathrm{CB}$ & $\mathrm{CB}$ & $\mathrm{CB}$ & $\mathrm{CB}$ & $\begin{array}{l}\text { CB, реже } \\
\mathrm{HCB}\end{array}$ & $\mathrm{CB}$ \\
\hline обследовать & $\mathrm{HCB}, \mathrm{CB}$ & $\mathrm{HCB}, \mathrm{CB}$ & $\mathrm{HCB}, \mathrm{CB}$ & $\mathrm{HCB}, \mathrm{CB}$ & $\mathrm{HCB}, \mathrm{CB}$ & $\mathrm{HCB}, \mathrm{CB}$ & $\mathrm{HCB}, \mathrm{CB}$ \\
\hline скандировать & $\mathrm{HCB}, \mathrm{CB}$ & $\begin{array}{l}\text { глагола } \\
\text { нет }\end{array}$ & $\mathrm{HCB}$ & $\mathrm{HCB}$ & $\mathrm{HCB}$ & $\mathrm{HCB}$ & \\
\hline соборовать & $\mathrm{HCB}, \mathrm{CB}$ & $\mathrm{HCB}, \mathrm{CB}$ & $\mathrm{HCB}, \mathrm{CB}$ & $\mathrm{HCB}, \mathrm{CB}$ & $\mathrm{HCB}, \mathrm{CB}$ & $\mathrm{HCB}, \mathrm{CB}$ & \\
\hline солировать & $\mathrm{HCB}, \mathrm{CB}$ & $\begin{array}{l}\text { глагола } \\
\text { нет }\end{array}$ & $\mathrm{HCB}$ & $\mathrm{HCB}, \mathrm{CB}$ & HCB & $\mathrm{HCB}, \mathrm{CB}$ & \\
\hline спонсировать & $\begin{array}{l}\text { глагола } \\
\text { нет }\end{array}$ & $\begin{array}{l}\text { глагола } \\
\text { нет } \\
\end{array}$ & $\mathrm{HCB}, \mathrm{CB}$ & $\mathrm{HCB}, \mathrm{CB}$ & $\mathrm{HCB}, \mathrm{CB}$ & глагола нет & \\
\hline стыковаться & $\mathrm{HCB}$ & $\begin{array}{l}\text { глагола } \\
\text { нет }\end{array}$ & $\mathrm{HCB}, \mathrm{CB}$ & $\mathrm{HCB}$ & $\mathrm{HCB}$ & $\mathrm{HCB}$ & \\
\hline тестировать & $\begin{array}{l}\text { глагола } \\
\text { нет }\end{array}$ & $\begin{array}{l}\text { глагола } \\
\text { нет }\end{array}$ & $\mathrm{HCB}, \mathrm{CB}$ & HCB & $\mathrm{HCB}, \mathrm{CB}$ & глагола нет & \\
\hline травмировать & $\begin{array}{l}\text { глагола } \\
\text { нет }\end{array}$ & $\begin{array}{l}\text { глагола } \\
\text { нет }\end{array}$ & $\mathrm{HCB}, \mathrm{CB}$ & $\mathrm{HCB}, \mathrm{CB}$ & $\mathrm{HCB}, \mathrm{CB}$ & $\mathrm{HCB}, \mathrm{CB}$ & \\
\hline централизовать & $\mathrm{HCB}, \mathrm{CB}$ & $\begin{array}{l}\text { глагола } \\
\text { нет }\end{array}$ & $\mathrm{HCB}, \mathrm{CB}$ & $\mathrm{HCB}, \mathrm{CB}$ & $\mathrm{HCB}, \mathrm{CB}$ & $\mathrm{HCB}, \mathrm{CB}$ & \\
\hline четвертовать & $\mathrm{HCB}, \mathrm{CB}$ & $\mathrm{HCB}, \mathrm{CB}$ & $\mathrm{HCB}, \mathrm{CB}$ & $\mathrm{HCB}, \mathrm{CB}$ & $\mathrm{HCB}, \mathrm{CB}$ & $\mathrm{HCB}, \mathrm{CB}$ & \\
\hline
\end{tabular}

Таблица 1: Представление видовой принадлежности двадцати глаголов - кандидатов на «двувидовость» в семи различных словарях

\footnotetext{
двувидовость фиксируется в соответствующем словаре; указания на более редкую встречаемость переданы аутентично.

${ }^{4}$ Сопоставление данных словарей с примерами из речи рассматриваются в следующем разделе статьи.

5 Для краткости столбцы обозначены фамилиями редакторов или авторов словарей либо принятыми сокращениями (ССРЛЯ, БАС). Поскольку Большой академический словарь русского языка (3-е издание) вышел еще не полностью (последний опубликованный том - 23-й из планируемых 30), то глаголы на буквы «С» и далее в алфавитном порядке по нему, к сожалению, не могут быть проверены, и соответствующие клетки таблицы не заполнены. Если же какой-либо глагол в том или ином словаре отсутствует, то в таблице зафиксировано: «глагола нет».
} 
Как видим, словари полностью единодушны относительно двувидовой принадлежности глаголов только в половине случаев (амнистировать, исповедовать, локализовать, напутствовать, обследовать, соборовать, спонсировать, травмировать, централизовать, четвертовать), - если отвлечься от того обстоятельства, что в некоторых словарях часть этих глаголов вовсе не упоминается, а также не учитывать того, что БАС вышел ещё не полностью - ведь не исключено, что для рассматриваемых здесь глаголов, которые будут появляться в следующих томах этого словаря, видовая принадлежность и там будет отличаться от приводимых здесь данных прочих словарей. Далее, мы видим, что для некоторых глаголов (надругаться, скандировать, стыковаться) лишь один из рассмотренных словарей указывает оба вида. Поскольку ДГ для анализа были отобраны в результате случайной выборки и на их месте могли бы оказаться любые иные ДГ, то логично предположить, что и по поводу некоторых других ДГ среди лексикографов нет единого мнения относительно их видовых характеристик.

Теперь стоит перейти от лексикографических описаний к практике.

\section{4 Сравнение лексикографических данных с примерами употребления}

\section{1 Описание материала}

Вид глаголов при их употреблении устанавливается автором данного исследования с опорой на интуицию. Поэтому в определении глагольных видов возможны спорные решения: не исключено, что если бы анализ производился другим лингвистом, мнения о видовой принадлежности глагола в том или ином его употреблении отчасти расходились бы. Поскольку сопоставление четырех текстовых корпусов - задача исключительно трудоемкая, в целях экономии времени для анализа были отобраны 8 глаголов из 20, представляющиеся наиболее перспективными для сравнения их употребления с их же лексикографическими характеристиками видовой принадлежности. Привлекаются следующие текстовые корпусы: ${ }^{6}$ Национальный корпус русского языка (НКРЯ, основной корпус), портал «Новая газета», портал «Аргументы и факты», портал «Эхо Москвы». Поскольку некоторые глаголы чрезвычайно частотны и вхождений оказывается более 200, автор поступает следующим образом: анализируются первые 50 вхождений и составляется статистика видовой принадлежности искомых глаголов по ним, методом сплошной выборки. Исключение делается только для НКРЯ, где рассматриваются 250 первых вхождений, ${ }^{7}$ поскольку это единственный корпус, в котором представлены различные жанры и типы текстов - а ведь употребление грамматических форм зависит не в последнюю очередь именно от них: в то время как в художественной или научной литературе, в мемуарах и эссе, в технической документации, в юридических документах употребление глагола в настоящем времени и, следовательно, в НСВ не редкость, в новостных заметках

\footnotetext{
${ }^{6}$ В этой работе термин «текстовый корпус» используется в широком значении: имеется в виду любой массив текстов в сети, для которых поддерживается функция поиска.

${ }^{7}$ Если вхождений для того или иного ДГ оказывалось менее 250, то рассматривалось соответствующее число найденных в НКРЯ примеров.
} 
глаголы (как и причастия) преимущественно употребляются в формах прошедшего, реже - будущего времени.

\section{2 Обоснование принятия решений}

Перед тем, как перейти непосредственно к таблице и комментариям к ней, требуется пояснить тактику принятия решений. Некоторые рекомендации по принятию решений относительно употребления глагольного вида описаны в академической Русской грамматике (§§1437-1454). Еще более подробно рекомендации по употреблению видов даны в книге: Найдич, Павлова 2015: 315-340.

Понятно, что контекст типа Каждыцй раз, когда мы обследуем эту местность... или Рано или поздно саперы обследуют местность $и$ обнаружат мины позволяют однозначно отнести глагол обследовать к НСВ в первом и к СВ во втором случае. Однако далеко не всегда контекст является столь надежным подспорьем. Например, в заголовке В Подмосковье спецслужбы обследуют местность на предмет торфяных пожаров видовая принадлежность того же глагола неясна: то ли Что делают? обследуют (сейчас), то ли Что сделают? - обследуют (в ближайшее время). Двусмысленность часто разрешается контекстом (в данном случае текстом соответствующей статьи), но далеко не всегда, как показывает опыт исследования текстовых корпусов.

В данном разделе необходимо подробно обосновать тактику принятия решений относительно приписывания изучаемым ДГ того или иного вида.

Если глагол используется в сочетании с грамматическим или лексическим отрицанием (кто-л. не будет/не станет/отказывается что-либо делать) или с модальными глаголами настоящего времени, а также словами, сопоставимыми с ними по функции (кто-л. не хочет/не может/не должен/кому-л. нельзя что-либо делать), такие случаи обычно расцениваются как НСВ - по правилам русской грамматики; при этом не имеет значения, употребляются ли модальные глаголы в деонтическом или эпистемическом значении. Впрочем, глаголы, явно тяготеющие к употреблению в СВ (типа обнародовать), в исследуемом материале зачислялись в группу «Неясные случаи» (Газета отказалась - что сделать/что делать? - обнародовать данный материал). Если глагол употребляется в форме инфинитива в рамках составного глагольного сказуемого, первая часть которого не предполагает однозначного причисления ДГ к тому или иному виду, т. е. не исключает трактовки ДГ и как СВ, и как НСВ (например, кто-л. боялся, планировал, предполагал - что делать/что сделать? - амнистировать или что-л. позволяет, кто-л. старается - что делать/что сделать? - интегрировать), то такие примеры также попадают в категорию «Неясные случаи». То же касается атрибутивной или объектной роли инфинитива при существительном (соблазн - какой? что делать/что сделать? - интегрировать; готовность - к чему? что делать/что сделать? - надругаться). Несмотря на то, что при модальных глаголах (и квазиглаголах) инфинитив чаще употребляется в СВ (нужно/можно/кто-л. должен сделать то-то и то-то), НСВ по правилам тоже не запрещён (ср. нужно приходить вовремя, можно разговаривать громко), поэтому случаи такого рода (нужно интегрировать 
людей в социальное пространство) также зачисляются в категорию «неясных» (разумеется, если контекст не позволяет принять однозначное решение). В той же группе оказываются фразы, для которых из контекста не вытекает, стоит ли глагол в личной форме в настоящем или простом будущем времени. Так, даже левый контекст с другим глаголом в НСВ часто не способен однозначно прояснить ситуацию. Например: Процесс этот идет в двух направления. С одной стороны, амнистируют политзаключенных (НКРЯ). Несмотря на употребление глагола идет в НСВ в левом контексте, соответствующая фраза может быть отнесена и к плану будущего; из-за этого видовой статус глагола амнистируют неясен; двусмысленность не снимается. Значительно реже возникают затруднения в определении видовой принадлежности глаголов в формах прошедшего времени; исключение составляют глаголы солировать (B концерте - что делала/что сделала? - солировала Анна-София Муттер), тестировать (Компания - что делала/что сделала? - тестировала новую технологию), надругаться (Кто над тобой - что делал/что сделал? - надругался?). Здесь перед нами, следовательно, тоже «неясные случаи», опять-таки если контекст допускает оба решения. Иногда вид глагола, употребленного в инфинитиве, то ли в настоящем, то ли в простом будущем, легко установить благодаря другим глаголам в том же предложении (например: Конечная цель - сделать страну частью Европь, интегрировать её в европейское политическое пространство - СВ; Его проклянут, а потомки надругаются над его памятью - CB; Нас угнетают, над нами надругаются $\mathrm{HCB})$.

Формы причастий и деепричастий также рассматриваются и входят в статистику (например, деепричастие обнародуя или причастие обжалуемый считаются ясными случаями НСВ). Страдательные причастия прошедшего времени (амнистированный) рассматриваются как представляющие $\mathrm{CB}$, несмотря на то, что в русском языке встречается небольшая группа страдательных причастий (в некоторых грамматиках они рассматриваются как прилагательные) $\mathrm{HCB}$ (жареный, стираный). Есть ДГ, для которых употребление причастных форм, особенно кратких, заметно превалирует над использованием личных (интегрирован) или просто чрезвычайно частотно (амнистирован, обнародован). Хотя соотношение личных, инфинитивных и причастнодеепричастных глагольных форм в текстовых корпусах представляет несомненную ценность для лексикографии, для данного раздела оно нерелевантно и здесь не приводится. О частотности некоторых глагольных форм, встретившихся в НКРЯ, можно узнать из таблицы 3.

Словоформы с постфиксом -ся игнорировались, так как при их рассмотрении добавляется трудность отделения актива от пассива. ${ }^{8}$ Не рассматривались и идиомы (Чему быть - того не миновать).

Некоторые тексты в порталах СМИ повторяются; в статистике повторы не учитываются.

\footnotetext{
${ }^{8}$ Ср.: «Основные трудности при подсчете и описании двувидовых глаголов заключаются в разнородных трактовках единиц с постфиксом -ся. Имеющиеся словарные источники исключительно непоследовательны в решении этого вопроса» (Горобец 2008: 22).
}

ISSN 1615-3014 


\section{3 Представление материала в табличной форме и комментарии}

\begin{tabular}{|c|c|c|c|c|}
\hline Глагол & НКРЯ & Новая газета & Аргументы и факты & Эхо Москвы \\
\hline амнистировать & $\begin{array}{l}\text { На } 219 \text { вхождений } \\
\text { СВ: } 191 \\
\text { НСВ: } 10 \\
\text { Неясные случаи: } 18\end{array}$ & $\begin{array}{l}\text { На } 50 \text { вхождений } \\
\text { СВ: } 50 \\
\text { НСВ: } 0 \\
\text { Неясные случаи: } 0\end{array}$ & $\begin{array}{l}\text { На } 50 \text { вхождений } \\
\text { СВ: } 41 \\
\text { НСВ: } 4 \\
\text { Неясные случаи: } 5\end{array}$ & $\begin{array}{l}\text { На } 50 \text { вхождений } \\
\text { СВ: } 45 \\
\text { НСВ: } 3 \\
\text { Неясные случаи: } 2\end{array}$ \\
\hline интегрировать & $\begin{array}{l}\text { На } 250 \text { вхождений } \\
\text { СВ: } 170 \\
\text { НСВ: } 51 \\
\text { Неясные случаи: } 29\end{array}$ & $\begin{array}{l}\text { На } 50 \text { вхождений } \\
\text { СВ: } 41 \\
\text { НСВ: } 0 \\
\text { Неясные случаи: } 9\end{array}$ & $\begin{array}{l}\text { На } 50 \text { вхождений } \\
\text { СВ: } 27 \\
\text { НСВ: } 12 \\
\text { Неясные случаи: } 11\end{array}$ & $\begin{array}{l}\text { На } 50 \text { вхождений } \\
\text { СВ: } 30 \\
\text { НСВ: } 6 \\
\text { Неясные случаи: } 14\end{array}$ \\
\hline миновать & $\begin{array}{l}\text { На } 250 \text { вхождений } \\
\text { СВ: } 164 \\
\text { НСВ: } 82 \\
\text { Неясные случаи: } 4\end{array}$ & $\begin{array}{l}\text { На } 50 \text { вхождений } \\
\text { СВ: } 49 \\
\text { НСВ: } 0 \\
\text { Неясные случаи: } 1\end{array}$ & $\begin{array}{l}\text { Выявить } \\
\text { необходимую } \\
\text { информацию не } \\
\text { было возможности, } \\
\text { см. комментарий } \\
\end{array}$ & $\begin{array}{l}\text { На } 50 \text { вхождений } \\
\text { СВ: } 35 \\
\text { НСВ: } 14 \\
\text { Неясные случаи: } 1\end{array}$ \\
\hline надругаться & $\begin{array}{l}\text { На } 250 \text { вхождений } \\
\text { СВ: } 131 \\
\text { НСВ: } 37 \\
\text { Неясные случаи: } 82\end{array}$ & $\begin{array}{l}\text { На } 50 \text { вхождений } \\
\text { СВ: } 28 \\
\text { НСВ: } 5 \\
\text { Неясные случаи: } 17\end{array}$ & $\begin{array}{l}\text { На } 50 \text { вхождений } \\
\text { СВ: } 39 \\
\text { НСВ: } 5 \\
\text { Неясные случаи: } 6\end{array}$ & $\begin{array}{l}\text { На } 50 \text { вхождений } \\
\text { СВ: } 41 \\
\text { НСВ: } 5 \\
\text { Неясные случаи: } 4\end{array}$ \\
\hline обжаловать & $\begin{array}{l}\text { На } 250 \text { вхождений } \\
\text { СВ: } 138 \\
\text { НСВ: } 49 \\
\text { Неясные случаи: } 63\end{array}$ & $\begin{array}{l}\text { На } 50 \text { вхождений } \\
\text { СВ: } 40 \\
\text { НСВ: } 4 \\
\text { Неясные случаи: } 6\end{array}$ & $\begin{array}{l}\text { На } 50 \text { вхождений } \\
\text { СВ: } 40 \\
\text { НСВ: } 5 \\
\text { Неясные случаи: } 5\end{array}$ & $\begin{array}{l}\text { На } 50 \text { вхождений } \\
\text { СВ: } 34 \\
\text { НСВ: } 8 \\
\text { Неясные случаи: } 8\end{array}$ \\
\hline обнародовать & $\begin{array}{l}\text { На } 250 \text { вхождений } \\
\text { СВ: } 225 \\
\text { НСВ: } 8 \\
\text { Неясные случаи: } 17\end{array}$ & $\begin{array}{l}\text { На } 50 \text { вхождений } \\
\text { СВ: } 48 \\
\text { НСВ: } 0 \\
\text { Неясные случаи: } 2\end{array}$ & $\begin{array}{l}\text { На } 50 \text { вхождений } \\
\text { СВ: } 47 \\
\text { НСВ: } 0 \\
\text { Неясные случаи: } 3\end{array}$ & $\begin{array}{l}\text { На } 50 \text { вхождений } \\
\text { СВ: } 43 \\
\text { НСВ: } 5 \\
\text { Неясные случаи: } 2\end{array}$ \\
\hline солировать & $\begin{array}{l}\text { На } 163 \text { вхождения } \\
\text { СВ: } 0 \\
\text { НСВ: } 152 \\
\text { Неясные случаи: } 11\end{array}$ & $\begin{array}{l}\text { На } 50 \text { вхождений } \\
\text { СВ: } 0 \\
\text { НСВ: } 36 \\
\text { Неясные случаи: } 14\end{array}$ & $\begin{array}{l}\text { На } 50 \text { вхождений } \\
\text { СВ: } 0 \\
\text { НСВ: } 44 \\
\text { Неясные случаи: } 6\end{array}$ & $\begin{array}{l}\text { На } 50 \text { вхождений } \\
\text { СВ: } 0 \\
\text { НСВ: } 46 \\
\text { Неясные случаи: } 4\end{array}$ \\
\hline тестировать & $\begin{array}{l}\text { На } 236 \text { вхождений } \\
\text { СВ: } 20 \\
\text { НСВ: } 170 \\
\text { Неясные случаи: } 46\end{array}$ & $\begin{array}{l}\text { На } 50 \text { вхождений } \\
\text { СВ: } 6 \\
\text { НСВ: } 27 \\
\text { Неясные случаи: } 17\end{array}$ & $\begin{array}{l}\text { На } 50 \text { вхождений } \\
\text { СВ: } 0 \\
\text { НСВ: } 35 \\
\text { Неясные случаи: } 15\end{array}$ & $\begin{array}{l}\text { На } 50 \text { вхождений } \\
\text { СВ: } 3 \\
\text { НСВ: } 38 \\
\text { Неясные случаи: } 9\end{array}$ \\
\hline
\end{tabular}

Таблица 2: Видовая принадлежность восьми ДГ по данным текстовых корпусов

Комментарии к таблице 2:

1) Как и ожидалось, заметное превышение $\mathrm{CB}$ над $\mathrm{HCB}$ для большинства рассмотренных глаголов в газетных статьях можно объяснить тем, что последние содержат по большей части новости об уже произошедших событиях или (реже) о намерениях (планах, проектах), т. е. преобладает семантика результата. Радио чаще, чем газеты, размещает на своем портале интервью, в которых в том числе употребляется настоящее время для повествования о текущих событиях. Однако приведенная здесь статистика радио-портала отличается от газетных лишь незначительно. Больше всего нарративности и потому употреблений настоящего времени встречается, конечно, в НКРЯ.

2) Портал «Аргументы и факты» в ответ на ввод в поисковую машину глагола миновать выдает любые примеры, где какое-либо слово начинается с мин-: 
минный, минуты, министерство, минор и проч. Из-за непомерных временны́х затрат обработка релевантного материала по этому глаголу на данном портале была прервана и соответствующая клетка не заполнена.

3) Употребления НСВ глагола миновать в текстах выявлены главным образом для деепричастия минуя (за исключением «Новой газеты», где оно не встретилось ни разу). Именно за счет деепричастия набирается относительно большое число употреблений НСВ на «Эхе Москвы». В то же время НКРЯ позволяет отчасти «выправить» эту статистику, обнаруживая немалое количество употреблений личных форм глагола миновать в однозначно настоящем времени, хотя и здесь за сравнительно высокое число НСВ в первую очередь ответственно деепричастие минуя. Эта странность заставляет предположить, что у деепричастия имеется какой-то особый статус, сближающий его с наречием или служебным словом. И действительно, при переводе на немецкий в большинстве случаев минуя передается предлогом an etw. vorbei (минуя какую-л. инстанцию - an einer Instanz vorbei). Синонимами минуя в одном из его значений (судя по всему, в текстах наиболее популярном) могут выступать предлоги: помимо, невзирая на и даже без. Это заставляет предположить, что учитывать данное деепричастие в группе НCB, вероятно, не стоило. Однако прямых указаний на то, что минуя не «истинное» деепричастие, а только его подобие, в справочной литературе по русской грамматике не отыскивается.

4) Для глагола солировать случаев однозначного употребления СВ (ожидаемо) не обнаружено. Ни одно из употреблений этого глагола в виде солирует невозможно расценить как простое будущее - это явно грамматическое настоящее, даже если отнесено к реальному будущему ( $B$ сегодняшнем концерте солирует...). Встретилось большое число употреблений сложного будущего (будет солировать) - однако не в НКРЯ, а в других источниках. Некоторые примеры в прошедшем времени (типа После окончания консерватории она - что делала/что сделала? солировала в Гентской опере) можно рассматривать двояко, что отмечено как «неясные случаи»: противопоставление видов здесь как будто снимается, становится нерелевантным.

5) Большое число СВ-употреблений для интегрировать объясняется частотностью причастий интегрирован, интегрированный, причем полная форма иногда может расцениваться и как прилагательное (интегрированные системы); однако при анализе не было возможности вникать в семантические тонкости словосочетаний.

6) Для глагола тестировать употребление в ипостаси СВ зафиксировано для личных форм прошедшего времени (например: Он тестировал sim-карту и обнаружил, что ...), однако значительно чаще эти формы зачислялись в группу «неясных случаев» (например, чрезвычайно частотны контексты типа кто-л. предлагает кого-л. - что делать/что сделать? - тестировать - то ли одноразово, то ли многократно). В то же время категория «СВ» для этого глагола пополнялась употреблениями причастия тестированный.

7) Некоторые ДГ в формах прошедшего времени однозначно трактуются как СВ (миновал, обнародовал, обжаловал), в то время как для других вопрос о видовой 
принадлежности остается открытым (тестировал, интегрировал) - в случае, если контекст не помогает принять решение. Формы минует, минуют и проч. трактуются то как $\mathrm{HCB}$, то как $\mathrm{CB}$ в зависимости от контекста и нередко пополняют группу «неясных случаев», в то время как обжалуют, обнародуют по большей части все же однозначно зачисляются в СВ. Инфинитивы глаголов миновать, обжаловать, обнародовать в составе сложных глагольных сказуемых с первой частью планирует, намерен, собирается также трактуются как СВ, в отличие от других глаголов списка: трудно представить себе ситуацию, когда автор сообщает, что он попытается/nостарается/nопробует что-либо - что делать? миновать. Ради единообразия все инфинитивы ДГ при модальных глаголах и квази-глаголах (а также их синонимах) расценивались как «неясные случаи» (разумеется, за исключением ясных индикаторов типа на протяжении многих лет, или по многу раз для НСВ). Большинство сказуемых с глаголом мочь (или синонимами - например, иметь право, допустимо) ожидаемо встретилось в сочетании с инфинитивом обжаловать в отрывках из юридических текстов (НКРЯ). Наиболее ясные случаи НСВ-употребления для того же глагола будет/будут обжаловать; они и составили группу НСВ.

\section{5 Частотность некоторых грамматических форм ДГ по данным НКРЯ}

Грамматические формы ДГ - чисто теоретически - должны образовываться по правилам обоих видов. Следовательно, будущее время они могут выражать как однословной формой - в своей СВ-ипостаси (он - что сделает? - централизует), так и сложной (он - что будет делать? - будет изентрализовать). Переходные глаголы должны иметь формы страдательных причастий как настоящего времени (централизуемый), так и прошедшего (иентрализованный). Однако априори ясно, что далеко не все ДГ образуют соответствующие формы. Так, конструкция кто-л. будет миновать кажется, мягко говоря, странной - во всяком случае, не узуальной, ${ }^{9}$ как и причастие минуемыци, не говоря уже о явно ненормативном *

В связи с анализом текстовых корпусов на предмет СВ- и НСВ-употреблений полезно проверить частотность встречаемости отдельных грамматических форм. Проверка осуществляется только по НКРЯ, как корпусу, приспособленному для поиска словоформ и словосочетаний. Учитываются любые варианты одной граммемы, т. е. формы для любого грамматического лица, числа и рода (там, где число и/или род релевантны). Поскольку страдательные причастия образуются только от переходных глаголов, для непереходных соответствующие клетки таблицы оставлены незаполненными. Если же та или иная искомая форма причастий для переходного глагола не найдена, то в графе стоит «0». Это не означает, однако, что соответствующая форма вообще не существует, - просто ее нет в НКРЯ. Если же форма представляется ненормативной, то в соответствующей графе стоит знак «*». По НКРЯ проверяется каждая граммема (форма каждого лица, числа, а также рода - для

\footnotetext{
9 Поэтому строка стихотворения И будут миновать ночные корабли Наветренный пролив и остров Гваделупа (А. Городницкий), несмотря на формальную нормативность, воспринимается по меньшей мере как странная, хотя в одноименной песне эта странность не замечается.
} 
причастий). Иными словами, поиск производится для словоформ: интегрирую интегрируешь и проч. - буду/будешь/будет и проч. интегрировать - интегрируемьй интегрируемого и проч./интегрируемая - интегрируемой и проч.). Однако в соответствующих графах выводится только общая сумма всех вхождений - для простоты восприятия и из экономии объема таблицы. Поскольку система поиска в НКРЯ не поддерживает различение лексико-семантических вариантов для многозначных слов, а также не дает возможности различать место ударения, то многозначный глагол исповедовать, который является двувидовым только в одном из своих значений, а также глагол брони́ровать, имеющий омограф бронирова́ть, не являющийся двувидовым, из списка проверяемых глаголов исключены. Не анализируется также граммема «страдательное причастие прошедшего времени» для глагола изентрализовать, поскольку причастие здесь омонимично прилагательному централизованный. Соответствующая ячейка таблицы оставлена пустой. ${ }^{10}$

\begin{tabular}{|l|l|l|l|l|}
\hline Глагол & $\begin{array}{l}\text { Простое будущее/ } \\
\text { настоящее }\end{array}$ & $\begin{array}{l}\text { Сложное } \\
\text { будущее }\end{array}$ & $\begin{array}{l}\text { Полное страдательное } \\
\text { причастие наст. вр. }\end{array}$ & $\begin{array}{l}\text { Полное страдательное } \\
\text { причастие прош. вр. }\end{array}$ \\
\hline амнистировать & 20 & 0 & 4 & 61 \\
\hline интегрировать & 49 & 3 & 31 & 940 \\
\hline локализовать & 23 & 0 & 15 & 157 \\
\hline миновать & 825 & 0 & 0 & $*$ \\
\hline надругаться & 52 & 1 & & 7 \\
\hline напутствовать & 90 & 2 & 90 & 32 \\
\hline обжаловать & 21 & 16 & 63 & 197 \\
\hline обнародовать & 54 & 1 & 0 & 39 \\
\hline обследовать & 99 & 5 & 89 & 8 \\
\hline скандировать & 55 & 0 & 2 & 0 \\
\hline соборовать & 2 & 2 & 0 & 3 \\
\hline солировать & 32 & 0 & & 12 \\
\hline спонсировать & 41 & 6 & 21 & 165 \\
\hline стыковаться & 84 & 0 & & 17 \\
\hline тестировать & 36 & 1 & 90 & 2 \\
\hline травмировать & 62 & 2 & 2 & 2 \\
\hline централизовать & 11 & 0 & 2 & \\
\hline четвертовать & 20 & 4 & 0 & \\
\hline
\end{tabular}

Таблица 3: Образование некоторых грамматических форм для 18 переходных двувидовых глаголов

Комментарии к таблице 3:

1) Некоторые словоформы в НКРЯ не обнаруживаются по причинам чисто количественным. Так, Основной корпус НКРЯ явно содержит очень малое число текстов, передающих диалогическую речь, а Устный подкорпус НКРЯ, несмотря на солидный объем (до 11,3 млн словоупотреблений), видимо, недостаточен, из-за чего формы 2 л. ед. и мн. ч. типа тестируешь, тестируете не встретились ни в Основном, ни в Устном корпусах, при том, что в диалогической речи, особенно на работе, реплики вроде Плохо тестируете! или Что ты теперь тестируешь?

\footnotetext{
10 Несмотря на то, что интегрированныци, травмированный во многих сочетаниях тоже можно расценивать как прилагательные, они здесь рассматриваются, так как их «генетическая» близость к причастию все же более ощутима, чем у слова цеентрализованный в его адъективной ипостаси.
} 
встречаются в диалогах - например, на компьютерных фирмах - повседневно. Это нужно иметь в виду и делать скидку на это при рассмотрении результатов, представленных в таблице: НКРЯ явно не отражает реального положения дел в русском дискурсе на $100 \%$.

2) Из-за неснимаемой омонимии форм четвертуюю и четвёртую проверить, есть ли вхождения для этой глагольной словоформы, было крайне затруднительно: вычитывание каждого примера в контексте и решение относительно значения словоформы отняло бы слишком много времени. Для всех прочих грамматических форм настоящего vs. простого будущего проверка удалась.

3) Сравнительно небольшая частотность простого будущего (настоящего?) для глаголов амнистировать, интегрировать, локализовать, обнародовать объясняется тем, что будущее время для соответствующих значений образуется чаще с помощью форм глагола быть плюс краткое причастие (будет амнистирован, интегрирован, локализован, обнародован) - в отличие от глаголов миновать, напутствовать.

4) Формы сложного будущего для глаголов амнистировать, локализовать, миновать, скандировать, солировать, стьковаться, иентрализовать в НКРЯ не встретились, а для глагола тестировать зафиксировано лишь одно вхождение. При этом интуитивно ясно, что будут локализовать, будут интегрировать, будут скандировать, будут стылкваться, будут тестировать сказать вполне можно (только лишь для формы будуm тестировать Google-поисковик дает 83700 попаданий!), в то время как будут амнистировать, будут миновать, будут централизовать - формы как минимум неузуальные, производящие впечатление странных (несмотря на это, поиск для будут амнистировать дает 1700 Googleвхождений, будут миновать - 1170, будут цеентрализовать - 760). Что же касается формы будет солировать, то для нее одной в Google обнаруживается более 11500 вхождений, а для формы будет стыковаться их даже более 36000, так что НКРЯ в данном случае оказывается не слишком надежным источником. Для формы будет травмировать Google-поисковик показывает 35700 попаданий. В то же время надо учитывать, что чаще говорят не что-л. будет кого-л. травмировать, а что-л. может кого-л. травмировать: ведь в данном случае сказуемое с модальным глаголом чаще всего выступает синонимом формы будущего времени. И действительно, для модели может травмировать Google демонстрирует свыше 86000 попаданий.

5) Для почти единодушного (за одним исключением) мнения авторов проверенных выше словарей относительно того, что глагол обжаловать совершенного вида, 16 вхождений по поиску форм сложного будущего (будут обжаловать, будем обжаловать) - слишком высокая цифра. Глагол этот явно двувидовой, и его лексикографическую аттестацию в качестве только «СВ» следовало бы пересмотреть. Удивляет низкое число употреблений в основном корпусе НКРЯ сложного будущего для глагола обследовать (5 вхождений): кого-л. будут обследовать в клинике - фраза, произносимая в диалогах очень часто (это подсказывает личный опыт; поиск в Google по маске будут обследовать приносит 
28500 попаданий). Проверка по Устному подкорпусу НКРЯ в этом отношении ничего нового не показала: там примеров сложного будущего еще меньше (3). Относительно этой граммемы приходится констатировать расхождение интуитивной и корпусной частотности.

6) Страдательные причастия настоящего времени минуемыци, обнародуемый, соборуемый несомненно, существуют, но их сравнительно редкая встречаемость в дискурсе обернулась при поиске в НКРЯ «нулевым» значением вхождений. Они производят впечатление грамматически странных, непривычных. Поиск по Google приносит порядка 1500 вхождений для словоформы минуемый, около 2000 для обнародуемый и менее 100 для соборуемый. Странность формы четвертуемый и его нулевая встречаемость в НКРЯ (против около 1100 непосредственно в Google) объясняется скорее не грамматически, а семантически либо прагматически: трудно представить себе тексты, в которых подобное причастие было бы уместным.

7) Для страдательного причастия прошедшего времени соборованный (соборованная, соборованные и проч.) в НКРЯ не обнаружено ни одного примера, тогда как в Google их отыскивается порядка 1000 только для формы мужского рода именительного падежа. Небывало высокое число вхождений для формы интегрированный (интегрированная, -ые и проч.) ожидаемо и объясняется тем, что это слово во многих словосочетаниях уже превратилось в прилагательное. У слова травмированный есть также как причастная, так и адъективная ипостаси, однако причастие все же, по всей видимости, в общей массе примеров превалирует. Довольно неожиданной оказалась высокая частотность причастия тестированный - предполагалось, что скорее для того же значения использовалась бы форма протестированный; проверка выявила, однако, для этого причастия лишь 16 вхождений.

Общий вывод из приводимой таблицы словоформ состоит в том, что все переходные глаголы, за исключением глагола миновать, образуют причастия как СВ, так и НCB, но частотность их употребления разная. Сложное будущее у некоторых ДГ в НКРЯ не зафиксировано, но это не является достоверным доказательством того, что эти формы не употребляются или что они ненормативны. Однако это в любом случае показатель их относительно редкой встречаемости.

\section{6 Восприятие форм двувидовых глаголов в письменной речи билингвами и монолингвами}

Чисто интуитивный подход к анализу (как в разделе 3) сопоставляется далее с экспериментальным: по методу опроса исследуется рецепция билингвами с первым языком русским, проживающими в Германии, и монолингвами - носителями русского языка, проживающими в России, некоторых фраз на письме, включающих ДГ. Группа билингвов в нашем случае - это студенты, приехавшие в Германию детьми, свободно владеющие немецким, но сохраняющие русский в качестве не только первого, но и 
доминантного (основного, «сильного») языка. ${ }^{11}$ Под «монолингвами» здесь обобщены люди, хотя и владеющие иностранными языками, но выучившие их в школе и/или университете и пользующиеся в быту и на работе исключительно или преимущественно русским языком.

Опрос включает две рубрики: сначала опрашивается мнение реципиентов относительно принадлежности глагольной формы к тому или иному виду, однако вид выясняется опосредованно, через грамматическое время; затем предлагается оценить меру нормативности и узуальности тех или иных форм. В первой части опроса глаголы стоят только в настоящем/простом будущем времени, во второй - в сложном будущем времени. Фразы намеренно лишены левого и правого контекста, чтобы информанты определяли грамматическое время и меру грамотности и/или узуальности фразы чисто интуитивно, самостоятельно «додумывая» возможный контекст. Все примеры взяты из текстовых корпусов в сети, т. е. ни одна из них не является выдуманной; однако большинство примеров упрощено. В самих фразах лексическое окружение не содержит подсказок о том, идет ли речь о будущем или о настоящем. Отвечавших в обеих группах было равное количество: по 30 человек.

Гипотезы, проверяемые первой частью опроса (см. таблицу 4), можно сформулировать следующим образом.

Гипотеза 1: Ответы «Возможно одно время, а возможно другое в зависимости от контекста» будут встречаться в целом реже, чем ответы «Это настоящее» (или «скорее настоящее» либо «Это будущее» (или «скорее будущее»).

Гипотеза 2: Для глаголов солировать, скандировать большинство ответов будет лежать в области настоящего времени, а для глаголов миновать, обжаловать в области будущего.

Гипотеза 3: Несмотря на хорошее владение русским, оценки билингвов и монолингвов относительно видовой принадлежности и меры грамотности/узуальности форм ДГ будут расходиться в плане их единообразия: ответы монолингвов будут более единодушными, чем ответы билингвов, где разброс мнений будет выше.

Гипотеза 4: Ответы монолингвов будут более «решительными»: так, при отнесении формы глагола к будущему или настоящему, большинство в этой группе будет отвечать не «скорее будущее» или «скорее настоящее», а «однозначно будущее» или «однозначно настоящее». Иными словами, монолингвами в сравнении с билингвами ответы под номерами 1 и 2 в сумме будут даваться чаще, чем ответы по типу 3 и 4.

Последние две гипотезы базируются на том, что билингвы с доминирующим русским, проживающие в иноязычном окружении, не столь много читают и не столь активно используют русский язык и потому «чувство языка» у них развито слабее, чем у

\footnotetext{
11 Считается, что дети российских иммигрантов разговаривают на так называемом Heritated Russian «эритажном русском» языке (Kagan/Dillon 2001; Полинская 2004; Выренкова и др. 2014) и составляют единую группу. Однако такой подход слишком упрощает реальную картину: по степени владения русским среди людей второго поколения иммигрантов выделяется несколько различных языковых подгрупп, одна из которых билингвы - носители русского как основного и активно и вполне грамотно его использующие в самых разных ситуациях, см. Павлова 2011; Pavlova 2016.
}

ISSN 1615-3014 
Анна Павлова: Некоторые особенности двувидовых глаголов и их восприятие

монолингвов, проживающих в русской языковой среде, из-за чего монолингвы будут давать более уверенные ответы. Возможные варианты ответов приводятся ниже.

\begin{tabular}{|c|c|c|}
\hline Фраза & $\begin{array}{l}\text { Ответы билингвов: } \\
\text { номер варианта ответа } \\
\text { - количество ответов } \\
\text { (по нисходящей) }\end{array}$ & $\begin{array}{l}\text { Ответы монолингвов: } \\
\text { номер варианта ответа - } \\
\text { количество ответов (по } \\
\text { нисходящей) }\end{array}$ \\
\hline $\begin{array}{l}\text { Я бронирую для нас с женой два билета на } \\
\text { ночной поезд Москва-Амстердам. }\end{array}$ & $\begin{array}{l}5-14 \\
1-13 \\
3-2 \\
2-1\end{array}$ & $\begin{array}{l}1-14 \\
5-12 \\
3-2 \\
2-1 \\
4-1 \\
\end{array}$ \\
\hline $\begin{array}{l}\text { Средств в распоряжении МЧС достаточно, } \\
\text { пожарные локализуют огонь. }\end{array}$ & $\begin{array}{l}1-15 \\
5-6 \\
3-5 \\
2-2 \\
4-1 \\
6-1\end{array}$ & $\begin{array}{l}1-14 \\
3-7 \\
5-5 \\
2-3 \\
4-1\end{array}$ \\
\hline $\begin{array}{l}\text { Рабочая группа обследует дорожные условия } \\
\text { на маршруте совместно с заказчиком. }\end{array}$ & $\begin{array}{l}5-16 \\
1-6 \\
4-4 \\
3-3 \\
2-1\end{array}$ & $\begin{array}{l}5-11 \\
1-10 \\
4-5 \\
3-4\end{array}$ \\
\hline $\begin{array}{l}\text { Во время этого перехода группа минует } \\
\text { несколько старых туристских стоянок. }\end{array}$ & $\begin{array}{l}2-10 \\
1-7 \\
5-5 \\
4-6 \\
3-2\end{array}$ & $\begin{array}{l}2-12 \\
5-8 \\
4-6 \\
1-4\end{array}$ \\
\hline $\begin{array}{l}\text { Новый архитектурный комплекс аккуратно } \\
\text { интегрируется в уже существующую застройку } \\
\text { Москвы. }\end{array}$ & $\begin{array}{l}5-12 \\
1-9 \\
4-3 \\
3-3 \\
2-3 \\
\end{array}$ & $\begin{array}{l}1-14 \\
5-8 \\
4-5 \\
3-3\end{array}$ \\
\hline $\begin{array}{l}\text { Общество с восторгом амнистирует этих } \\
\text { преступников, прощая и мордобой, и угрозу } \\
\text { ножом, и кражи. }\end{array}$ & $\begin{array}{l}1-8 \\
5-8 \\
4-8 \\
3-6\end{array}$ & $\begin{array}{l}1-8 \\
5-8 \\
4-7 \\
3-6 \\
2-1\end{array}$ \\
\hline $\begin{array}{l}\text { Красные, для которых нет ничего святого, } \\
\text { надругаются над усопшими. }\end{array}$ & $\begin{array}{l}1-9 \\
3-9 \\
2-8 \\
5-2 \\
4-2\end{array}$ & $\begin{array}{l}2-13 \\
4-6 ; \\
1-4 \\
6-3 \\
3-2 \\
5-2\end{array}$ \\
\hline Мы обжалуем это решение суда. & $\begin{array}{l}2-21 \\
4-4 ; \\
5-4\end{array}$ & $\begin{array}{l}2-19 ; \\
4-9 ; \\
5-2\end{array}$ \\
\hline $\begin{array}{l}\text { Демонстранты скандируют в мегафон: Morire } \\
\text { con dignità! }\end{array}$ & $1-30$ & $\begin{array}{l}1-27 \\
3-3\end{array}$ \\
\hline $\begin{array}{l}\text { Отец Панкратий соборует и исповедует } \\
\text { больную. }\end{array}$ & $\begin{array}{l}5-14 \\
3-6 \\
1-5 \\
4-3\end{array}$ & $\begin{array}{l}1-11 \\
5-9 \\
3-4 \\
4-3\end{array}$ \\
\hline
\end{tabular}




\begin{tabular}{|c|c|c|}
\hline & $2-2$ & $2-3$ \\
\hline $\begin{array}{l}\text { На сцене Московской филармонии солирует } \\
\text { блистательная Наталия Гутман. }\end{array}$ & $\begin{array}{l}3-19 \\
2-6 ; \\
1-4 ; \\
4-1\end{array}$ & $\begin{array}{l}1-21 \\
3-5 ; \\
3-3 ; \\
4-1\end{array}$ \\
\hline $\begin{array}{l}\text { Перед прыжком с парашютом инструктор ещё } \\
\text { раз напутствует курсантов. }\end{array}$ & $\begin{array}{l}1-14 \\
3-8 ; \\
2-8\end{array}$ & $\begin{array}{l}1-21 \\
3-5 ; \\
5-3 ; \\
4-1\end{array}$ \\
\hline
\end{tabular}

Таблица 4: Ответы на вопрос о грамматическом времени. Возможные варианты ответов:

1. Однозначно настоящее время; 2. Однозначно будущее время; 3. Скорее настоящее время; 4. Скорее будущее время; 5. Настоящее или будущее в зависимости от контекста; 6. Затрудняюсь с ответом.

Комментарии к таблице 4:

Гипотезы 3 и 4 не подтверждаются: разброс мнений у билингвов с основным русским, проживающих в Германии, и у монолингвов, проживающих в России, не различается, и тенденция к большей уверенности суждений (по типу «только так, а не иначе») у монолингвов не прослеживается. Не подтверждается и гипотеза 1: ответ по типу «Возможно, это настоящее, а возможно, будущее в зависимости от контекста» встречается не реже, чем ответы по типу «только/скорее одно время». Что до гипотезы 2, то она подтверждается лишь отчасти: скандировать опознается действительно в подавляющем большинстве случаев обеими группами как глагол несовершенного вида, в то время как для глагола солировать ответы оказались не столь однозначны, хотя тенденция к тому, чтобы рассматривать его как НCB, явно прослеживается. Не исключено, что 7 ответов билингвов в пользу будущего времени объясняются тем, что последние не всегда различают употребление грамматического настоящего времени в значении будущего и собственно будущее время как грамматическую категорию - не исключено, что тут косвенно сказывается влияние немецкого, где футур настойчиво и успешно вытесняется презенсом. Возможно, о том же говорит относительно высокое число ответов (8) в той же группе билингвов в пользу «однозначно будущее» для глагола напутствовать, в то время как среди монолингвов лишь один человек склонялся к будущему времени. Глагол обжаловать трактовался большинством в обеих группах как $\mathrm{CB}$, глагол миновать скорее тоже, хотя 9 билингвов зачислило его в категорию НСВ, и немало людей в обеих группах посчитали, что решение должно зависеть от контекста. Заметно разошлись группы в оценке глаголов надругаться и соборовать. О причинах этих расхождений можно только гадать. Не исключено, что ситуация с «красными», для «которых нет ничего святого» и которые «надругаются над усопшими», большей частью монолингвов была воспринята как чьи-то размышления о ближайшем будущем (придут «красные» и надругаются над усопшими - видимо, «белыми»), в то время как в представлении билингвов, с раннего детства проживающих в Германии, «широкий контекст» подобного рода отсутствовал.

Относительно второй части опроса, посвященной определению меры корректности/привычности, также были выдвинуты гипотезы. 
Гипотеза 1. Среди билингвов будет больше ответов «Затрудняюсь с ответом», чем среди монолингвов.

Гипотеза 2. Как некорректные или странные будут расцениваться формы сложного будущего от глаголов, которые воспринимаются скорее как СВ (ср. табл. 4): миновать, обжаловать.

Гипотеза 3. Как странные или некорректные будут восприниматься фразы со сложным будущим от глаголов, которые чаще используются то ли в настоящем, то ли в простом будущем времени, когда речь идет о будущем: что-л. кого-л. травмирует (в значении ,может травмировать'); что-либо cmapmyem тогда-то (в недалеком будущем), кто-л. что-л. оборудует (к такому-то сроку), кто-л. что-л. централизует, локализует тогда-то (в будущем). Эта привычность связана с семантикой моментального или быстрого (непротяженного) действия (стартовать, травмировать) либо с семой результативности: даже если центтализовать или оборудовать что-л. можно долго, но на практике важен только результат.

Гипотеза 4. Для остальных глаголов (спонсировать, тестировать, солировать, стыковаться, четвертовать) форма сложного будущего будет восприниматься подавляющим большинством как грамматически корректная.

\begin{tabular}{|c|c|c|}
\hline Фраза & Ответы билингвов & Ответы монолингвов \\
\hline $\begin{array}{l}\text { Мартовский фестиваль будет спонсировать } \\
\text { фонд «Эстетика». }\end{array}$ & $\begin{array}{l}1-15 \\
2-8 \\
3-7\end{array}$ & $\begin{array}{l}1-19 \\
2-8 \\
3-3\end{array}$ \\
\hline $\begin{array}{l}\text { Этот пролив корабли будут миновать только } \\
\text { ночью. }\end{array}$ & $\begin{array}{l}1-13 \\
2-9 ; \\
3-7 \\
4-1\end{array}$ & $\begin{array}{l}3-14 \\
1-9 \\
2-7\end{array}$ \\
\hline $\begin{array}{l}\text { Российские космические корабли будут } \\
\text { стыковаться по-новому. }\end{array}$ & $\begin{array}{l}1-16 \\
2-8 ; \\
3-3 ; \\
4-3\end{array}$ & $\begin{array}{l}1-22 \\
2-5 \\
3-2 ; \\
4-1\end{array}$ \\
\hline $\begin{array}{l}\text { Этот фильм, получивший приз Каннского } \\
\text { фестиваля, на российских экранах будет } \\
\text { стартовать в марте. }\end{array}$ & $\begin{array}{l}3-14 \\
2-9 \\
1-7\end{array}$ & $\begin{array}{l}3-14 \\
2-10 \\
1-6\end{array}$ \\
\hline $\begin{array}{l}\text { Наши программы будут тестировать } \\
\text { профессиональные тестеры. }\end{array}$ & $\begin{array}{l}1-16 \\
2-10 \\
3-4\end{array}$ & $\begin{array}{l}1-21 \\
2-7 \\
3-2\end{array}$ \\
\hline $\begin{array}{l}\text { В сиквеле «Заклятье» будут солировать звёзды } \\
\text { сериалов. }\end{array}$ & $\begin{array}{l}1-18 \\
2-8 \\
3-4\end{array}$ & $\begin{array}{l}1-16 \\
2-10 \\
3-4\end{array}$ \\
\hline $\begin{array}{l}\text { Мы непременно в ближайшее же время будем } \\
\text { обжаловать этот вердикт. }\end{array}$ & $\begin{array}{l}3-22 \\
2-6 \\
1-2\end{array}$ & $\begin{array}{l}3-15 \\
1-10 \\
2-5\end{array}$ \\
\hline $\begin{array}{l}\text { Такие переживания будут травмировать } \\
\text { неустойчивую детскую психику. }\end{array}$ & $\begin{array}{l}2-12 \\
3-10 \\
1-8\end{array}$ & $\begin{array}{l}1-14 \\
2-11 \\
3-5\end{array}$ \\
\hline $\begin{array}{l}\text { Питание школьников будут централизовать и } \\
\text { улучшать его качество. }\end{array}$ & $\begin{array}{l}3-18 \\
2-9 \\
1-3\end{array}$ & $\begin{array}{l}3-16 \\
2-12 ; \\
1-2\end{array}$ \\
\hline
\end{tabular}




\begin{tabular}{|l|l|l|}
\hline Фирмы "Тоуота" и "Nissan" будут локализовать & $2-14 ;$ & $2-16 ;$ \\
сборку в странах Азии. & $1-7 ;$ & $1-5 ;$ \\
& $3-7 ;$ & $3-7 ;$ \\
\hline Преступника будут четвертовать в пятницу на & $4-2$ & $4-2$ \\
Соборной площади. & $2-8 ;$ & $1-11 ;$ \\
\hline Фирма "Инктома" будет оборудовать & $3-8$ & $2-11 ;$ \\
новосибирское отделение банка новой & $2-11 ;$ & $3-8$ \\
техникой. & $1-9 ;$ & $3-11 ;$ \\
& $3-9 ;$ & $2-10 ;$ \\
\hline
\end{tabular}

Таблица 5: Ответы на вопрос о мере грамотности/привычности. Возможные варианты ответов: 1. Фраза грамматически корректна; 2. Фраза производит впечатление странной; 3. Фраза грамматически некорректна; 4. Затрудняюсь с ответом.

Комментарии к таблице 5:

Гипотезу 1 (билингвы будут менее уверены в свои оценках) нельзя считать подтвержденной: билингвы лишь незначительно отличались от монолингвов мерой уверенности в своих оценках, так что ответов «Затрудняюсь» в этой группе так же мало, как и в другой. Гипотеза 2 (сложное будущее глаголов миновать, обжаловать будет расценено большинством как некорректное) подтвердилась лишь отчасти: несмотря на то, что большинство информантов в обеих группах посчитало форму будут миновать странной либо некорректной, 13 билингвов и 9 монолингвов оценили эту форму как грамматически корректную. Что до глагола обжаловать, то, несмотря на ожидаемое большинство ответов по типу 3 (некорректно), 10 респондентов из группы монолингвов посчитали форму будем обжаловать за корректную. В этом группа монолингвов заметно разошлась с группой билингвов. Не исключено, что объяснить это можно тем, что в российской прессе сложное будущее время для этого глагола регулярно встречается (см. табл. 2 и 3), а билингвы тестируемой группы с российской прессой знакомы плохо. Гипотезу 3 (сложное будущее от глаголов моментального действия или глаголов, в которых важнее всего сема результативности будет оценено большинством как странное или некорректное) можно рассматривать также как подтвержденную, хотя и не полностью: несмотря на то, что большинство в обеих группах рассматривали формы сложного будущего от глаголов cmapmoвать, травмировать, оборудовать, локализовать, централизовать как странные, немало респондентов дали и прямо противоположные ответы. Например, для глагола травмировать мнение относительно странности или некорректности в группе монолингвов превалирует лишь незначительно. Гипотеза 4 (сложное будущее для глаголов с процессуальной семантикой будет расценено большинством как корректное) не подтверждается: тех, кто рассматривает формы будет/будуm спонсировать, тестировать, солировать, стыковаться как грамматически корректные, нельзя назвать абсолютным или подавляющим большинством; иногда мнения делились пополам (например, для спонсировать в группе билингвов), а форму будут четвертовать большинство в обеих группах и вовсе расценили как странную или некорректную. 


\section{7 Зависимость оценки глагольного вида для ДГ от места главного ударения в устной речи}

Для ответа на вопрос, существует ли корреляция между главным (наиболее сильном) ударением на глаголе из группы ДГ и опознаванием его формы как представителя настоящего/простого будущего времени в устной речи, был проведен небольшой эксперимент с 10 монолингвами. Им заранее было объявлено, что контрастные значения (по типу $\mathrm{Mbl}$ не собираемся заезжать в деревню, мы мину́ем ее) в воображаемом контексте не участвуют, а затем было предложено выбрать, какая из двух услышанных фраз могла бы начинаться с согласия: Хорошо, ...; Ладно, ... Фразы произносились автором данной статьи, следовали парами и различались только местом наиболее сильного ударения:

Mbl оборудуем школьные помещения компью́терами. - Mbl обору́дуем школьные помещения компьютерами.

Мыл минуем опасную зо́ну. - Мыл мину́ем опасную зону.

Мы тестируем вашу новую програ́мму. - Мы тести́руем вашу новую программу.

Мы спонсируем ваш кинофестива́ль. - Мы спонси́руем ваш кинофестиваль.

Священник соборует больну́ю. - Священник собо́рует больную.

Ожидаемо все испытуемые ответили, что вторые фразы каждой пары можно начать со слова Хорошо, ... или Ладно, ..., потому что им слышится в них обещание сделать чтото в будущем, в то время как первые фразы каждой пары являются констатациями фактов, сообщениями о происходящем в данное время. Следовательно, понимание глагола как СВ может оказаться связано с семантикой речевого акта «Обещание», а как $\mathrm{HCB}$ с семантикой нарратива (повествовательности, чистой информативности).

\section{8 Заключение}

Исследование, проведенное в рамках настоящей работы, показывает, что при определении видовой принадлежности глаголов полагаться на словари нужно с осторожностью. В то время как относительно двувидовости некоторых глаголов (например, амнистировать) словари единодушны, относительно других высказываются разные мнения, вплоть до того, что лишь один словарь из рассмотренных семи считает глагол двувидовым (например, надругаться), - примеры демонстрируют иногда прямо противоположную тенденцию (см. Табл. 1). Так, амнистировать используется в его НСВ-ипостаси значительно реже, чем надругаться. ${ }^{12}$ Это побуждает предположить, что описание глаголов в лексикографии как двувидовых основана скорее на традиции, чем на анализе текстов.

Тем не менее, сопоставление нескольких словарей дает возможность довольно точно определить реально двувидовые глаголы: даже если один из словарей из нескольких сравниваемых (в данном случае один из семи) рассматривает какой-либо глагол как

\footnotetext{
12 Да и обилие «неясных случаев» употребления (Табл. 2) косвенно свидетельствует о том, что глагол надругаться заслуживает его оценки как двувидовой во всех одноязычных словарях.
}

ISSN 1615-3014 
двувидовой, обычно в текстовых корпусах можно найти для этого основания. Из всех проверенных по текстовым корпусам глаголов единственным, «аттестацию» которого как двувидового стоило бы, вероятно, в лексикографии пересмотреть, является глагол солировать. Оснований для причисления его к ДГ не обнаружено; немногочисленные «неясные случаи» при поиске по текстовым корпусам были отмечены только для употреблений этого глагола в прошедшем времени, когда контекст не указывает непосредственно ни на протяженность, ни на многократность действия. Но даже и в этих употреблениях данный глагол все же скорее выступает как НСВ - таков стереотип восприятия. С другой стороны, мнение почти половины каждой группы испытуемых относительно странности или даже ненормативности фразы, включающей сказуемое будут солировать, настораживает (см. Табл. 5). Впрочем, не исключено, что оценка фразы относилась не столько к глагольной форме как таковой, сколько к предложению в целом: как может быть, чтобы несколько «звёзд» одновременно солировали в одном сериале? Стилистическое несовершенство фразы, возможно, принимается за грамматическое.

Для глагола скандировать НКРЯ обнаруживает наличие форм страдательного причастия как настоящего, так и прошедшего времени, что косвенно указывает на двувидовость этого глагола. Однако опрос однозначно показывает, что этот глагол воспринимается в настоящем/простом будущем как НСВ (т. е. как форма настоящего времени) - по крайней мере, в нейтральном контексте.

Несмотря на малое число употреблений некоторых глаголов в СВ (например, тестировать) или, наоборот, в НСВ (например, обнародовать), нельзя сбрасывать эти употребления со счетов и игнорировать их. Формулировка «Таким небольшим количеством можно пренебречь» для нашего случая никак не подходит. Должны быть причины, по которым люди произносят буду обжаловать или будем обнародовать вместо обжалую и обнародуем (простое будущее время). По-видимому, отсутствие соответствующего удобного для употребления глагола $\mathrm{HCB}$, не дающее возможности выразить мысль в настоящем времени, заставляет превращать глагол типа обжаловать в двувидовой: Ходим по инстанциям, обжалуем приговор. Из этой потребности проистекает и возможность создания формы будем обжаловать - например, если человеку предстоит несколько раз обжаловать какое-либо судебное решение. Воспринимается этот глагол в своей НСВ-ипостаси как непривычный, однако эта ипостась родилась из практической надобности.

Невзирая на то, что текстовые корпуса в сети постоянно пополняются и потому статистика, составленная сегодня, не будет соответствовать статистике, составляемой по тем же критериям уже даже через месяц, примерное соотношение форм, повидимому, будет сохраняться. Понятно, что приводимые в настоящем исследовании данные демонстрируют не столько точные пропорции, сколько общие тенденции. Примечательно, что употребление ДГ в том или ином виде, а также в формах инфинитивов, причастий или деепричастий не в последнюю очередь определяется жанром текста. Новостные заметки, своды законов и правил, деловая переписка или техническая документация, реклама или художественная литература - жанр играет очень существенную роль в том, встречаем ли мы форму ДГ в сочетании с модальным глаголом, в составе сложных сказуемых с первой частью намерен, планирует, 
собирается, в виде предикатива, представленного кратким причастием, и т.п. Поэтому поиск по разным типам текстовых корпусов может дать очень разные результаты.

Проведенный опрос по восприятию ДГ в письменной речи билингвами и монолингвами показал, во-первых, отсутствие заметных различий в восприятии видовременных форм ДГ между двумя опрошенными группами. Это еще раз косвенно подтверждает необходимость дифференцировать группу, которую в последнее время все активнее именуют «людьми с эритажным русским». Среди второго поколения иммигрантов есть люди с основным русским, не делающие ошибок в глагольном виде и тонко его чувствующие, а есть люди с основным немецким, делающие, как и немцы, изучающие русский язык, ошибки в глагольном виде; причем даже при виртуозном владении русским языком ошибки этого типа в речи таких билингвов не исчезают. Вовторых, мы видим, что формы настоящего (или простого будущего) и сложного будущего времени воспринимаются по-разному в зависимости от конкретного глагола и что разброс мнений довольно высок как у билингвов, так и у монолингвов. Примечательно и то, что далеко не всегда реципиенты однозначно определяют вид глагола - по крайней мере, во фразах, не содержащих специальных подсказок типа наречий каждый раз, долго, однажды и проч. Немало было дано ответов по типу «Возможен один или другой вид в зависимости от контекста». Это отличает данное исследование от тех, что описаны в разделе 2, и противоречит гипотезе о том, что в каждом отдельном случае употребления вид ДГ определяется однозначно - либо как $\mathrm{CB}$, либо как НСВ. Расхождения в выводах между разными работами свидетельствует о необходимости проведения дальнейших экспериментов.

Несмотря на разброс мнений информантов, для отдельных ДГ можно установить некоторые тенденции. По всей вероятности, восприятие определенных глаголов как НCB или как СВ (или как обоих возможных вариантов), а также оценка формы сложного будущего как корректной или некорректной (либо странной) зависит в первую очередь от частотности употребления ДГ в дискурсе в том или ином грамматическом виде. В памяти людей хранятся модели словосочетаний и целых фраз, которые благодаря частотности закрепляются в сознании как эталоны. Отклонения от эталонов могут восприниматься как странные и даже грамматически неверные. В этой связи представляется чрезвычайно интересным исследование «субъективной частотности» при восприятии русских глагольных пар, описываемое в статье Anstatt/Clasmeier (2012). По мнению авторов, восприятие информантами тех или иных глаголов как частотных или редких дополняет данные, получаемые по текстовым корпусам. С другой стороны, субъективная частотность, систематически не соответствующая частотности искомых единиц в корпусах, не может не вызывать у исследователей обоснованные сомнения в ее надежности. Однако в любом случае исследование Anstatt/Clasmeier подтверждает предположение об оправданности разделения глаголов видовых пар на Alpha (сильные, привычные, узуальные) и Betha (слабые, неузуальные, кажущиеся странными).

При проведении подобных опросов необходимо также помнить, что та или иная фраза может показаться реципиенту некорректной не из-за формы глагола, а из-за чисто стилистических погрешностей: обычно людям трудно бывает отделить стилистику от грамматики, и под оценкой «грамматически некорректно» может скрываться смысл 
,стилистически некорректно“. При этом восприятие фразы как стилистически безупречной или обнаруживающей стилистические несовершенства во многом чисто субъективно (например, одна из участниц эксперимента в личном разговоре сообщила, что для нее любое сложное будущее представляется канцеляризмом и уже поэтому вызывает неприятие). Кроме того, как грамматическое будущее время может восприниматься грамматическое настоящее, если реципиент считает, что речь идет о реальном будущем. При проведении экспериментов на восприятие и оценку нормативности видо-временных форм все эти аспекты необходимо принимать во внимание.

Существует ли корреляция между наличием у глагола пары - перфективной (тестировать - протестировать, стылковаться - состыковаться, жениться пожениться) или, наоборот, имперфективной (организовать - организовывать, реализовать - реализовывать) - и опознанием соответствующего глагола как СВ или как НСВ, установить в рамках данного исследования не представлялось возможным слишком мала была выборка соответствующих глаголов. Этим, несомненно, стоило бы заняться в ближайшем будущем. Углубляя тему, важно было бы проверить, имеется ли корреляция между семантикой ДГ, означающих быстрое или моментальное действие (амнистировать, аннулировать, аттестовать, обнародовать), а также действие, которое само по себе обладает протяженностью, но в котором важен результат (короновать, суммировать, резюмировать), и их преимущественной оценкой как СВглаголов - и наоборот, ДГ, означающих протяженное (тестировать, напутствовать, солировать) или прерывистое и обычно многократно повторяющееся действие (скандировать, парировать) и их восприятием - опять-таки в нейтральных текстах при прочих равных условиях (например, только в прошедшем времени) как НСВ.

Далее, чрезвычайно интересной представляется тема «Причины и способы образования имперфективных и перфективных пар для ДГ». Ведь вряд ли образование пар для одних глаголов и необразование таковых для других является чистой случайностью. В психолингвистических экспериментах по этой теме можно было бы, в частности, протестировать и меру креативности в образовании форм, не зафиксированных словарями, и морфологические модели для словотворчества. ${ }^{13}$

Корреляция между трактовкой ДГ как $\mathrm{CB} / \mathrm{HCB}$ и местом главного ударения в устной речи (если отвлечься от фактора «контраст», который способен оправдать любые сильные ударения), объясняется не столько семантикой конкретных глаголов или их видовыми особенностями, сколько интонационным оформлением типов речевых актов. Так, для обещания типичен сильный фразовый акцент на глаголе (И мы найде́м ответ на вопрос! Mbl испо́лним вашу волю, капитан!) - впрочем, как и для угрозы (Mы вас вй́ведем на чистую воду!), ${ }^{14}$ в то время как повествовательность оформляется преимущественно конечным фразовым ударением. Глаголы в обещаниях чаще всего употребляются в СВ (по типу,Я это сделаю'). Данная интонационная маркировка

\footnotetext{
${ }^{13} \mathrm{Cp} .:$ Потехина 2007; работу в этом направлении стоило бы продолжить, усилив психолингвистическую и экспериментальную составляющую.

14 Приведенные здесь примеры заимствованы из Мультимедийного корпуса русского языка (подкорпуса НКРЯ): http://ruscorpora.ru/search-murco.html [09.05.2017].
}

ISSN 1615-3014 
характерна для фраз с любыми глаголами, независимо от их видовой принадлежности, но в случае с ДГ она помогает опознать глагол как представитель СВ.

Несомненно то, что несмотря на теоретическую возможность создания форм, связанных как с СВ, так и с НСВ двувидовых глаголов - сложного будущего, страдательного причастия настоящего времени (для переходных глаголов), деепричастия настоящего времени в случае НСВ-ипостаси или страдательного причастия прошедшего времени для СВ-ипостаси, - в реальности одни из этих форм являются узуальными и воспринимаются как привычные, а другие нет, вплоть до восприятия их как ненормативных. ${ }^{15}$ Чрезвычайно интересно и то, что некоторые глаголы можно трактовать в речи как воплощение только одного вида (как будто двуликий Янус повернулся к нам одним своим лицом, а о втором мы в это время не помним), другие как воплощение обоих видов одновременно (второе лицо двуликого Януса просвечивает сквозь первое), а для третьих видовое противопоставление оказывается попросту нерелевантным: Они женятся в субботу то ли в грамматическом будущем, то ли в грамматическом настоящем, то ли это $\mathrm{HCB}$, то ли $\mathrm{CB}$ - и это, в сущности, неважно; главное, что речь идет о реальном будущем. При этом говорящий, по всей вероятности, имеет в виду все же только либо СВ, либо НСВ употребляемого им глагола. Впрочем, и это предположение требует проверки, поэтому к экспериментам по восприятию и толкованию ДГ, которые должны, несомненно, продолжаться, стоило бы добавить исследования по речепорождению и рефлексии глагольного вида со стороны говорящего.

Изучение двувидовых глаголов, их употребления и восприятия - одна из ярких иллюстраций «полевого устройства» языковой системы: есть случаи ясные, типичные, «ядерные», и есть периферийные, постепенно смещающиеся в «соседние поля» сопоставимых множеств языковых явлений. Бинарность глагольной оппозиции «СВ $\mathrm{HCB}$ » в русском языке можно рассматривать как центральную часть полевого устройства категории глагольной аспектуальности. Однако, как справедливо замечает Плунгян, «формальная бинарность аспектуальных систем славянских языков почти нигде не является ни чистой, ни абсолютной: это лишь доминирующая тенденция» (Плунгян 2012: 17). Двувидовые глаголы образуют периферию поля глагольного вида, а внутри поля двувидовых глаголов имеются, в свою очередь, яркие носители соответствующего свойства и маргинальные, приближающиеся к границе другого поля - одновидовых глаголов. «Двувидовость» некоторых глаголов (особенно, похоже, тех, у которых образовались перфективные или имперфективные пары) поддерживается иногда наличием причастных форм (типа тестированный) или покоится на лексикографической традиции (как в случае глагола солировать).

Полевую систематизацию языковых явлений Павлов называл «естественной», «реальной» (Павлов 1998: 33): «Полевой подход к структуре языковой системы оптимальным образом соответствует на современном этапе развития лингвистической теории и методологии задачам освещения объекта изучения в его универсальных и в его идиоэтнических, конкретно-языковых характеристиках с равноправным,

\footnotetext{
15 К подобному же выводу приходит автор исследования глагольных ассоциаций, в частности, с двувидовыми глаголами-стимулами, ср.: Риехакайнен (2014).
}

ISSN 1615-3014 
взаимоуравновешенным учетом дискретности составляющих его «единиц» и континуальности языковой системы - одного из важнейших устоев ее целостности» (там же: 32). Именно периферийные явления особенно интересны для изучения, так как в них проявляется сложная, противоречивая природа языковой системы: «... в языке трудно найти противопоставления пар классов явлений, границы которых, улавливаемые определениями, обобщающими признаки максимально специфических представителей соответствующих классов, не имели бы в тех или иных отношениях, как принято говорить, «размытый», «текучий» характер. Это значит, что наряду со связями оппозитивного типа <..> важнейшую роль в обеспечении континуальности языковой (парадигматической) системы играют в ее структуре «промежуточные звенья» (там же: 29).

Исследование ДГ в очередной раз демонстрирует диалектичность языковой системы, ее динамику и имманентные ей единство и борьбу противоречий между стремлением участников коммуникации к логической однозначности (исключение составляют случаи намеренной двусмысленности - языковая игра) и наличествующей в языковой системе грамматической омонимией.

\section{Список использованных словарей}

Daum, Edmund/Schenk, Werner (1954): Die russischen Verben. Leipzig: VEB Bibliograph Institut.

Кузнецов, Сергей (ред.) (2006): Большой толковый словарь русского языка. СанктПетербург: Норинт.

Горбачевич, Кирилл (ред.) (2004 - наст. время): Большой академический словарь русского языка в 30 томах (БАС). Санкт-Петербург: Изд-во «Наука», с 2004 по наст. время.

Зализняк, Андрей (2010): Грамматический словарь русского языка. Изд. 6-е. Москва: Аст-Пресс.

Ожегов, Сергей/Шведова, Наталия (1996): Толковый словарь русского языка. Москва: Рос. АН, Ин-т русского яз.

Павлова, Анна (2012): Список одно- и двувидовых глаголов. https://docs.google.com/ spreadsheets/d/1rSOacfOMU8bnV9h80A1zRUsqgO4OatkJzUyKCB6iLQ/edit\#gid=0 [25.02.2016].

Словарь современного русского литературного языка в 17 томах (ССРЛЯ) (Ред.): Василий И. Чернышёв. Москва, Ленинград: Изд-во АН СССР, 1948-1965.

Толковый словарь русского языка в 4-х томах (Ред.): Дмитрий Н. Ушаков. Москва: ОГИЗ, Гос. изд-во иностранных и национальных словарей, 1935-1940.

\section{Литература}

Anstatt, Tanja/Clasmeier, Christina (2012): „Wie häufig ist ,poplakat“? Subjektive Frequenz und russischer Verbalaspekt“". Wiener Slawistischer Almanach 70: 129-163.

Ballweg, Joachim (1988): Die Semantik der deutschen Tempusformen. Eine indirekte Analyse im Rahmen einer temporal erweiterten Aussagelogik. Düsseldorf: Schwann. 
Chromý, Jan (2014): "Impact of Tense on the Interpretation of Bi-Aspectual Verbs in Czech". Studie z aplikované lingvistiky/Studies in Applied Linguistics 5/2: 87-97.

Gladney, Frank (1982): "Biaspectual Verbs and the Syntax of Aspect in Russian". The Slavic and East European Journal 26/2: 202-2015.

Janda, Laura (2007): “Aspectual clusters of Russian verbs”. Studies in Language 31/3: 607648.

Jung, Walter (1967): Grammatik der deutschen Sprache. Leipzig: VEB Bibliographisches Institut.

Kagan, Olga/Dillon, Kathleen (2001): “A New Perspective on Teaching Russian: Focus on the Heritage Learner". The Slavic and East European Journal 45/3: 507-518.

Pavlova, Anna (in Ersch.): „Sprachliche Normbrüche russischer ImmigrantInnen zweiter Generation in Deutschland im Vergleich mit sprachlichen Trends im heutigen Russland“. In: Witzlack-Makarevich, Kai/Wulff, Nadja (eds.): Handbuch des Russischen in Deutschland. Berlin: Frank \& Timme.

Lehmann, Volkmar (1993): „Die russischen Aspekte als gestufte Kategorien. Ein Beispiel für die Bedeutung der kognitiven Linguistik in der slavistischen Sprachwissenschaft" ${ }^{\text {". Welt }}$ der Slaven 38: 265-297.

Piperski, Alexander (2016): Between imperfective and perfective: quantitative approaches to the study of Russian biaspectual verbs. https://www.academia.edu/21426579 /Between_imperfective_and_perfective_quantitative_approaches_to_the_study_of_Russia n_biaspectual_verbs [21.03.2016].

Авилова, Наталья (1968): «Двувидовые глаголы с заимствованной основой в русском литературном языке нового времени». Вопросы языкознания 5: 66-78.

Выренкова, Анастасия/Полинская, Мария/Рахилина, Екатерина (2014): «Грамматика ошибок и грамматика конструкций: „эритажный“ („унаследованный“) русский язык». Вопросы языкознания 3: 3-19.

Гаспаров, Борис (2006): «Лингвистика национального самосознания. (Значение споров в 1860-1870 гг. о природе русской грамматики в истории философской и филологической мысли) ». Логос 1: 482-507.

Горобец, Елена (2008): Двувидовые глаголь в современном русском языке: проблемы статуса и классификации. Автореф. канд. филол. наук. Казань.

Зализняк, Анна/Микаэлян, Ирина/Шмелев, Алексей (2015): Русская аспектология: 8 защиту видовой napbl. Москва: Языки славянской культуры.

Найдич, Лариса/Павлова, Анна (2015): Трубочист или лорд? Теория и практика немецко-русского и русско-немеикого перевода. Москва: Златоуст.

Павлов, Владимир (1998): «Полевой подход и континуальность языковой системы». В кн.: Общее языкознание и теория грамматики: Материалы чтений, посвященных 90-летию со дня рождения С.Д. Каџнельсона. Санкт-Петербург, Наука: 28-40.

Павлова, Анна (2011): «Речь русских эмигрантов и билингвов: ошибки или тренды?» В кн.: Цейтлин, Стелла Наумовна (Ред.): Путь в язык. Одноязычие и двуязычие. Москва, Языки славянской культуры: 294-306.

Петрухина, Елена (2009): Русский глагол: категории вида и времени (в контексте современных лингвистических исследований). Учебное пособие. Москва: МАКС Пресс. 
Полинская, Мария (2010): «Русский язык первого и второго поколения эмигрантов, живущих в США». Slavica Helsingiensia 40: 336-352.

Потехина, Яна (2007): Префиксальная видовая пара русского глагола и ее отражение в словаре. Москва: Дис. канд. филол. наук.

Плунгян, Владимир (2012): «Предисловие» к кн.: Казанский, Николай (Ред.): Исследования по теории грамматики. Вып. 6: Типология аспектуальных систем и категорий. Acta Linguistica Petropolitana. T. VIII, часть II. Ст. Петербург, Наука: 7-42.

Риехакайнен, Елена (2014): «Видовые пары глаголов и ассоциативные связи в ментальном лексиконе носителя русского языка». В кн.: Богданов, Сергей/Меньшикова, Юлия (Ред.): XLII Междунар. филол. конф.: избр. трудыл. Санкт-Петербург, Филологический факультет СПбГУ: 265-274. http://mfk.spbu.ru /sites/default/files/riekhakaynen.pdf [15.03.2016].

Русская грамматика. Академия наук СССР, Институт русского языка. Раздел «Употребление видов». http://rusgram.narod.ru/1437-1454.html [09.05.2017].

Тихонов, Александр (1998): Русский глагол: проблемь теории и лексикографирования. Москва: Academia.

Черткова, Марина/Чанг, Пей-Чи (1998): «Эволюция двувидовых глаголов в современном русском языке». Russian Linguistics 22: 13-34. 